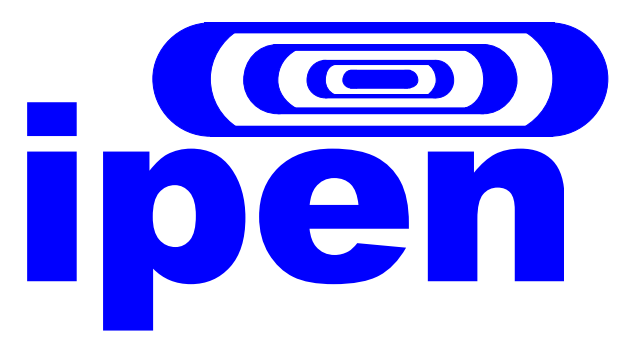

INSTITUTO DE PESQUISAS ENERGÉTICAS E NUCLEARES

Autarquia Associada à Universidade de São Paulo

\title{
ESTUDO DO REAPROVEITAMENTO DA BORRACHA DE CLOROPRENO PELA APLICAÇÃO DA TECNOLOGIA DE MICROONDAS
}

\section{SANDRA REGINA SCAGLIUSI}

Dissertação apresentada como parte dos requisitos para obtenção do Grau de Mestre em Ciências na Área de Tecnologia Nuclear - Materiais

Orientadora: Dra Sumair Gouveia de Araújo 
A minha mãe uma vida de apoio e compreensão 


\section{Agradecimentos}

- A Deus, a graça de estar simplesmente viva, e de poder ter chegado até aqui. Foi justamente no primeiro ano do Mestrado, que um "incidente" - bem no meio de um tremendo clima acadêmico - acrescentou um milhão de motivos para que eu possa dizer Graças a Deus.

- Ao Instituto de Pesquisas Energéticas e Nucleares pela oportunidade da realização deste trabalho.

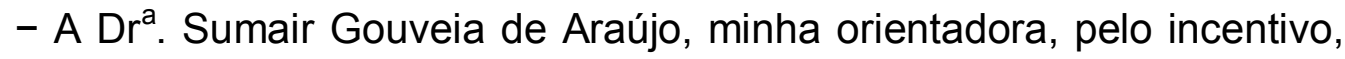
pelos conselhos, pela dedicação, pela amizade, pela compreensão e apoio em todos os momentos, meus profundos agradecimentos.

- Ao CQMA, pela oportunidade de realização deste trabalho, especialmente ao Dr. Ademar Benevolo Lugão, o meu muito obrigada.

- A Anvil Indústria e Comércio Ltda., especialmente aos diretores Eduardo Castellari e Anita Claudia Castellari, e aos funcionários José Roberto Velho e Nilson Pesoa de Oliveira, pelo incentivo, colaboração e apoio técnico que foram prestados durante o tempo de preparação deste trabalho, a vocês muito obrigada.

- A Dr ${ }^{a}$. Liliane Landini, pela ajuda prestada, pelo apoio, amizade e boa vontade na elaboração deste trabalho, meus sinceros agradecimentos.

- A Rosemeire dos Santos Moraes, pela amizade e colaboração sempre presente durante o tempo de preparação deste trabalho, muito obrigada.

- Ao meu pai Vito (In Memorium), a minha mãe, Mathilde, que esteve sempre presente incentivando, ajudando com carinho e dedicação. Sem o seu apoio a caminhada seria mais árdua.

- Ao meu marido Roberto, pelo apoio e carinho e por vivenciar todas as dificuldades ao longo desse período.

- Ao grupo de polímeros do CQMA, muito obrigada 


\section{Agradecimentos}

- Para toda a minha família, em particular aos meus irmãos Mariangela e Antonio Vitor, meus cunhados Paulo e Fatima e aos meus sobrinhos Mauricio, Daniela, Gabriela e Guilherme, pelo incentivo, carinho e apoio ao longo do caminho, nem sempre fácil, muito obrigada.

- Aos meus amigos e amigas, que embora não tenham contribuído diretamente, estão sempre ao meu lado.

- Ao Sr. Douglas Riozo Takasi, pela colaboração, muito obrigada.

- A empresa Primatex, especialmente ao Sr. Aloisio pela colaboração, muito obrigada.

- A minha amiga Silvia Valeria Ludovico, pela amizade e colaboração, muito obrigada.

- A todos os meus colegas de trabalho, pelo apoio e paciência, obrigada.

- A todas as outras pessoas, que direta ou indiretamente, contribuíram positivamente para a realização deste trabalho. 


\title{
ESTUDO DO REAPROVEITAMENTO DA BORRACHA DE CLOROPRENO PELA APLICAÇÃO DA TECNOLOGIA DE MICROONDAS
}

\author{
Sandra Regina Scagliusi
}

RESUMO

A borracha de cloropreno é utilizada na confecção de diversos artefatos, como roupas de mergulho e de ginástica, revestimentos de cabos, pneumáticos especiais e na indústria calçadista, entre outros. Apesar de propiciar muitos benefícios, um dos problemas enfrentados atualmente é reaproveitar estes artigos de borracha vulcanizados usados ou com vida útil esgotada, bem como sobras de produção, visando a preservação do meio ambiente. A devulcanização destes produtos pode ser realizada por meio de processos biológicos, químicos e físicos. O objetivo principal deste trabalho foi estudar a reciclagem/reaproveitamento (devulcanização) do cloropreno (DuPont - Neoprene $®$ ), pelo processo físico de microondas. Para tanto foi elaborada uma formulação básica com este tipo de borracha, para uso na indústria automobilística. As irradiações das amostras foram feitas em equipamento gerador de microondas desenvolvido no CQMA do IPEN, que opera com freqüência de $2450 \mathrm{MHz}$ e potências de $1.000 \mathrm{~W}$ a $3.000 \mathrm{~W}$. As análises das amostras irradiadas com microondas e não irradiadas, foram feitas por meio de ensaios de dureza, densidade, deformação permanente a compressão (DPC), tração, alongamento, cinzas, swelling, teste de envelhecimento e reometria. Os resultados mostraram que a borracha de cloropreno irradiada com microondas apresentou tendência de vulcanizar novamente e poderá substituir algumas partes da borracha virgem em formulações, sem provocar grandes perdas nas propriedades físico-químicas. 


\title{
A STUDY OF CHLOROPRENE RUBBER REUSE BY MICROWAVE TECHNOLOGY APPLICATION
}

\author{
Sandra Regina Scagliusi
}

\begin{abstract}
The chloroprene rubber is used to make several artefacts, such as diving and gymnastics outfits, cables coating, special pneumatic automobile tires, and in the shoe industry, among others. In spite of its benefits, a great problem nowadays is to recycle these used or with their lifetime expired galvanized articles, aiming to preserve the environment. The devulcanization of these products may be carried out by biological, chemical and physical processes. The amin target of this work was to study the chloroprene recycling/re-use (DuPont - Neoprene®), by the physical microwave process. For this purpose, a basic formulation was done with this kind of rubber, to be used in the automobile industry. The samples irradiations were performed in microwave generator equipment, developed at the CQMA of the IPEN, which operates with a frequency of $2,450 \mathrm{MHz}$ and power of $1,000 \mathrm{~W}$ to $3,000 \mathrm{~W}$. The analyses of the samples irradiated with microwave and with those not irradiated were done by means of hardness, density, permanent deformation and compression (DPC), traction, stretching, ash, swelling, aging test and reometry assays. The results showed that the chloroprene rubber irradiated with microwage presented a trend to vulcanize again and may substitute some unused rubber parts in formulations, without causing considerable losses in the phisicalchemical properties.
\end{abstract}




\section{SUMÁRIO}

Página

1 INTRODUÇÃO

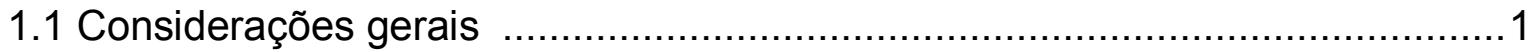

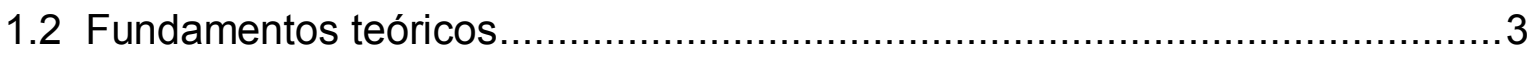

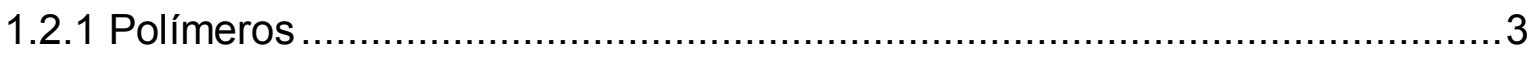

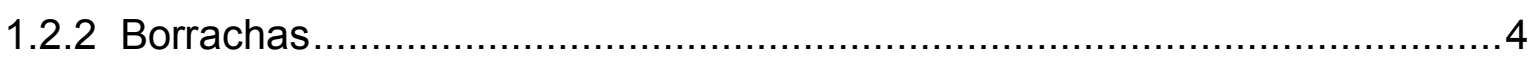

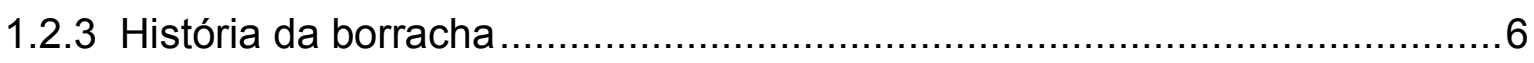

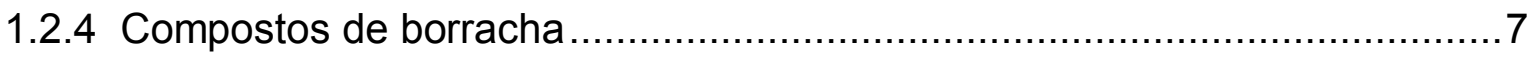

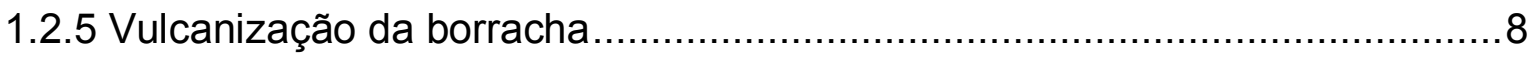

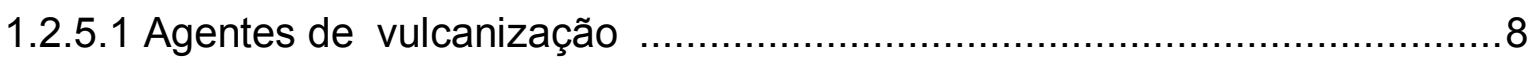

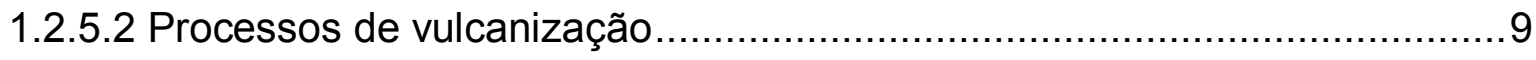

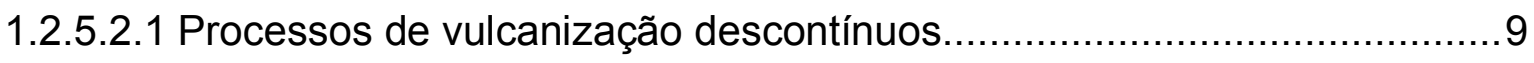

1.2.5.2.2 Processos de vulcanização contínuos ............................................. 10

1.2.6 Devulcanização e recuperação da borracha ............................................11

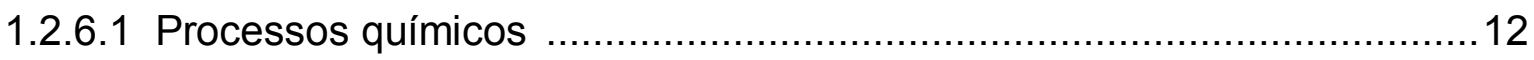

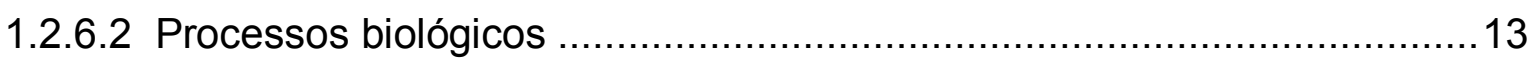

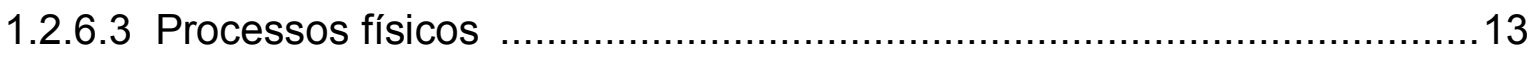

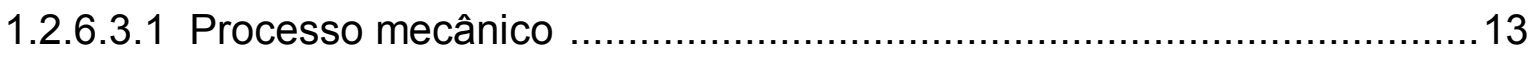

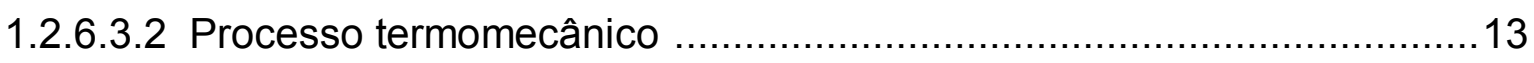

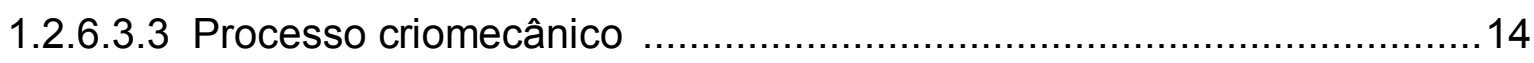

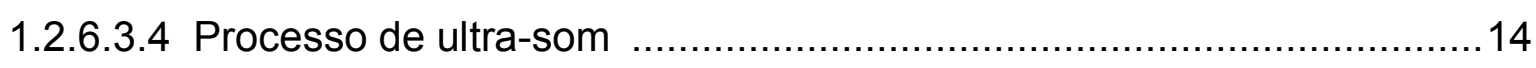

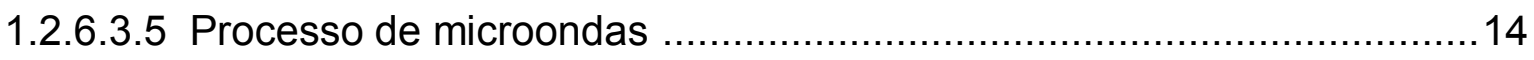

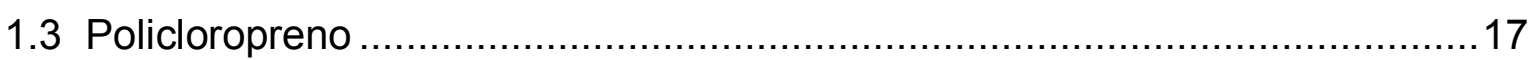

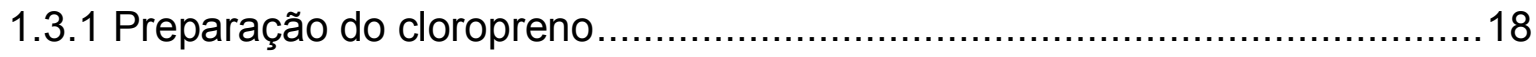

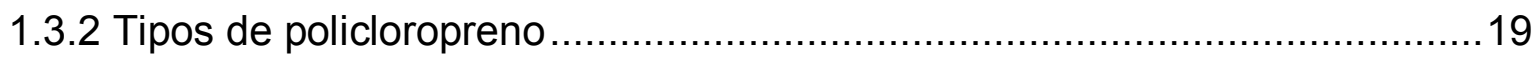

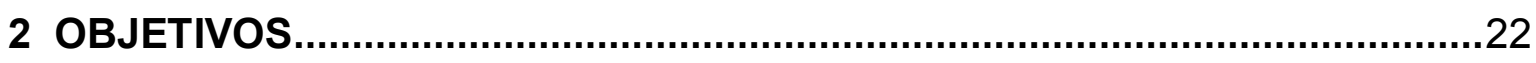

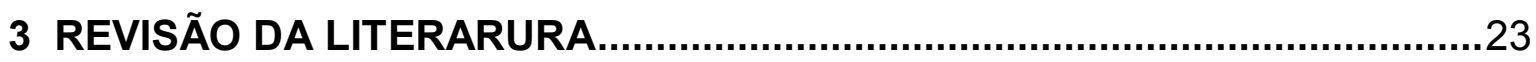




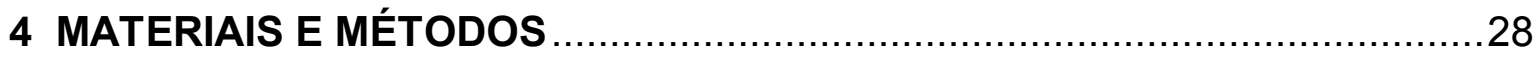

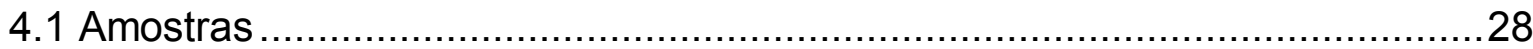

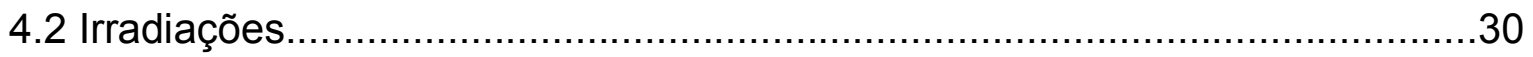

4.3 Processamento e Caracterização .......................................................... 31

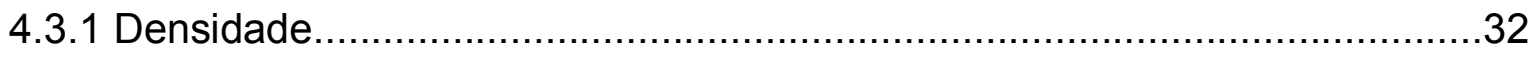

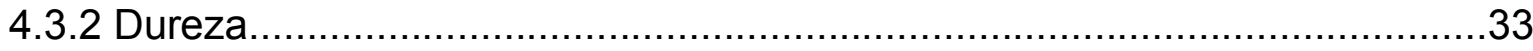

4.3.3 Resistência a Tração e Alongamento.....................................................3

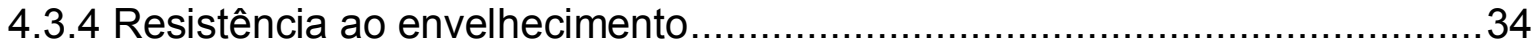

4.3.5 Deformação permanebte por compressão (DPC) .................................. 35

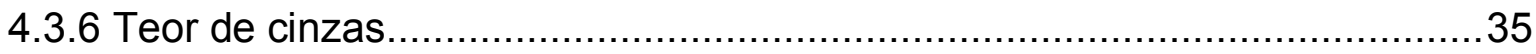

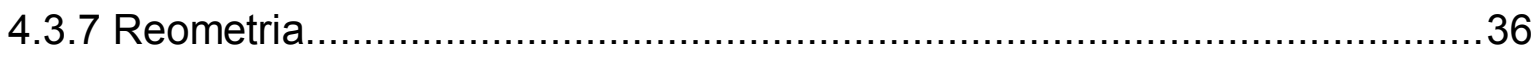

4.3.8 Determinação de gel, índice de inchamento (swelling) e fuidez (DSV) .......37

5 RESULTADOS E DISCUSSÕES.................................................................. 38

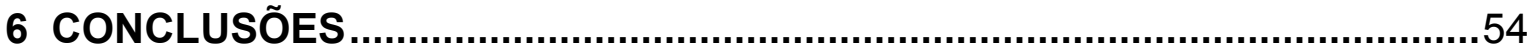

REFERÊNCIAS BIBLIOGRÁFICAS ........................................................... 56 


\section{INTRODUÇÃO}

\subsection{Considerações Gerais}

Um dos maiores problemas enfrentados na preservação do meio ambiente é o gerenciamento dos resíduos de materiais poliméricos, antes e após o consumo, ou seja, sobras de produção e artefatos usados. A coleta seletiva de lixo é um dos caminhos utilizados para administrar a disposição destes produtos. Porém, a estrutura para tratamento dos resíduos, ainda se baseia na simples destinação à queima (energeticamente aproveitada ou não) ou doação/venda à atividade sucateira, que após a seleção, lavagem e regranulação, o recoloca no mercado para misturar com resinas virgens, barateando, assim, o novo processamento. A atividade deste setor se aplica aos materiais termoplásticos, que com novo aquecimento, apresentam comportamento propício à nova extrusão ou injeção.

Com relação aos polímeros reticulados (termofixos), principalmente os elastômeros vulcanizados (mais conhecidos como borrachas vulcanizadas), tal comportamento não se verifica. Normalmente, estes resíduos são queimados, destinados ao aterro sanitário ou, no máximo, utilizados como carga inerte (após moagem e pulverização), em aplicações diversas, ou mesmo no próprio processo que o originou (neste caso, com deterioração das propriedades mecânicas do produto final e com o benefício do barateamento).

Como os materiais poliméricos não se decompõem facilmente, a disposição destes resíduos tem se tornado um sério problema ambiental. No caso de sobras de borracha, principalmente pneus, muitos são descartados e dispostos em aterros. Em outras situações, são usados como combustível, sendo incinerados para produzir eletricidade. Além disso, os custos são bastante elevados. Portanto, a reciclagem e a recuperação se apresentam como as melhores opções de gerenciamento. Por estes motivos, em todo o mundo, têm sido desenvolvidos diversos processos, para a reutilização e recuperação destes materiais. Eles consistem na conversão de um polímero termofixo em um produto termoplástico, mais fácil de processar, essencialmente passível de ser revulcanizado, com propriedades semelhantes às da borracha virgem ${ }^{1}$. 
A borracha possui diversos tipos e pode ser encontrada em vários produtos, que são utilizados nos seguintes setores: indústria automobilística (pneus, câmaras de ar, coxins, guarnições, retentores); hospitais (cateteres, garrotes, luvas cirúrgicas, próteses); brinquedos (bolas, balões, máscaras, bonecos, moldados, estilingues); vestuário (elásticos diversos, tecidos emborrachados, meias); calçados (solados, sandálias, adesivos); serviços (luvas isolantes, luvas domésticas, isolantes diversos), além de preservativos, tapetes, entre outros. Pode-se concluir, pela sua ampla utilização, que a borracha se transformou num item indispensável ao cotidiano do ser humano ${ }^{2}$.

Entre todos os tipos, uma tem se destacado, o cloropreno - CR (nome genérico de Neoprene ${ }^{\circledR}$ - DuPont), primeiro elastômero sintético comercializado (1932). Ele é bastante versátil, podendo ser vulcanizado com enxofre ou peróxidos orgânicos, possuindo as seguintes características: especiais, como proteção isotérmica, boa elasticidade, leveza, possibilita a transpiração; técnicas, como resistência a óleo, solventes, intempéries, calor, oxigênio, ozônio, luz solar, temperaturas elevadas, chama e tração. Desta maneira, pode ser utilizado em diversas aplicações: revestimentos de cabos, pneumáticos especiais, calçados, produtos ortopédicos, roupas esportivas (eqüestres, de mergulho e de ginástica), entre outros ${ }^{3}$.

Apesar de todos os benefícios obtidos com a vulcanização das borrachas (descoberta por Goodyear, em 1839), é difícil devulcanizá-las. Sendo assim, o processo reversível da vulcanização de borrachas, chamado de devulcanização, tem sido amplamente estudado, com o objetivo de romper as ligações cruzadas, principalmente entre carbono-enxofre (C-S) e enxofre-enxofre (S-S). Este método é empregado como uma maneira de recuperar/reciclar borrachas podendo levar à economia de alguns recursos de petróleo, bem como resolver os problemas de disposição ${ }^{1}$. Isto permite que os produtos retornem como carga ativa,ou seja, conferem propriedades físicas mecânicas como: rigidez, resistência à tração, compressão, deformação e rasgamento ou como carga inerte (materiais de enchimento), que não melhoram em nada estas propriedades, ao contrário, até pioram, porém aumentam o volume do material reduzindo assim os custos $^{4}$, em vez de serem despejados em depósitos ou aterros.

A devulcanização e recuperação destes produtos pode ser realizada por meio de processos biológicos, químicos e físicos (mecânico, termomecânico, 
criomecânico, ultra-som e microondas). Dentre todos estes, um tem se destacado: o processo físico de microondas ${ }^{5}$. Pesquisas estão sendo realizadas mundialmente, para identificar (qualitativamente e quantitativamente) e definir os mecanismos de interação destas ondas eletromagnéticas com os materiais. No Brasil, este é um campo bem recente, e está sendo aplicado como uma nova ferramenta para processamento destes materiais. Mais especificamente, este método tem mostrado melhores resultados para borrachas nitrilícas (NBR), cloropreno (CR) e polímeros que possuem grupos polares ${ }^{6}$.

\subsection{Fundamentos Teóricos}

\subsubsection{Polímeros}

Os polímeros são substâncias constituídas de macromoléculas formadas de unidades estruturais, repetidas várias vezes, ligadas quimicamente entre si, ou seja, consistem de um número indefinido de unidades monoméricas. As massas molares podem variar de cerca de vinte mil até milhões de $\mathrm{g} / \mathrm{mol}^{4,7}$.

Há muita semelhança entre os conceitos de macromolécula e polímero. Macromoléculas são moléculas grandes, de elevado peso molecular, o qual decorre de sua complexidade química, podendo ou não ter unidades químicas repetidas. A palavra polímero (poly + mer, muitas partes) vem do grego e foi criado por Berzelius, em 1832, para designar compostos de pesos moleculares múltiplos, em contraposição ao termo isômero (isomer), empregado para compostos de mesmo peso molecular, porém de estruturas diferentes, como acetileno e benzeno. Polímeros são macromoléculas caracterizadas por seu tamanho, estrutura química e interações intra e intermoleculares. Possuem unidades químicas ligadas por covalências, repetidas, regularmente ao longo da cadeia, denominadas meros. O número de meros da cadeia polimérica é denominado grau de polimerização, sendo geralmente simbolizado por $n$ ou $D P$ (Degree of Polymerization) $^{8}$.

Os materiais poliméricos podem ser divididos em duas categorias principais: termoplásticos e termorrígidos. Os termoplásticos são aqueles que apresentam a habilidade de fundir e refundir após serem solidificados, enquanto os termorrígidos são aqueles que solidificam através de reações químicas de 
cura, proporcionando uma estrutura molecular reticulada, conforme mostrado na FIG.1. Estes polímeros reticulados não podem ser refundidos após a solidificação ${ }^{9}$.

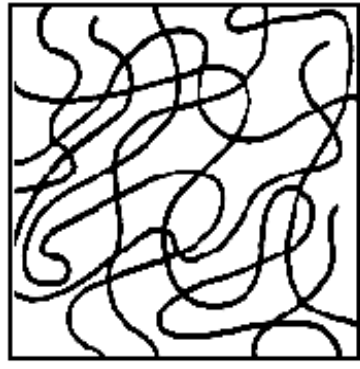

Polímero Linear

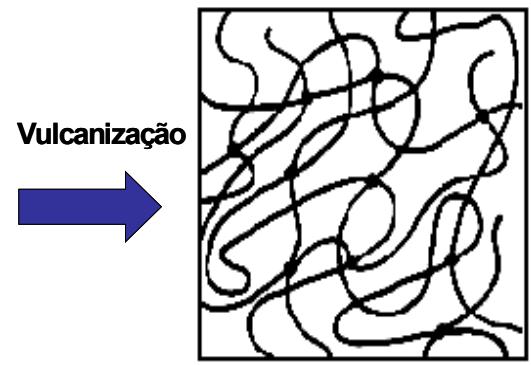

Polímero Reticulado

Figura 1 - Estrutura Molecular dos Polímeros.

\subsubsection{Borrachas}

A borracha natural é encontrada na forma de emulsão, o látex natural ou vegetal é a matéria-prima proveniente de túbulos microscópicos da casca de certas árvores que apresentam secreção leitosa (látex natural), dentre as quais a Hevea Brasiliensis, nativa da Amazônia, é a que fornece o produto de melhor qualidade ${ }^{4}$. O termo borracha, em português; teve origem quando ela foi utilizada para a fabricação de botijas, em substituição às borrachas de couro, que eram usadas para transportar vinho e água, posteriormente, passaram a ser fabricadas de látex. Este termo (borracha) passou a significar o material contido no látex e aplicou-se a todos os polímeros sintéticos, com propriedades semelhantes a ele. Dentre todos os materiais poliméricos, as borrachas se distinguem por sua característica única de permitir alongamento, seguido instantaneamente de quase completa retração, especialmente quando se encontram na condição vulcanizada. Esse fenômeno foi primeiramente observado na borracha natural, e passou a ser reconhecido como elasticidade ${ }^{8}$. Existem hoje mais de 500 tipos e variedades de borrachas, que podem ser classificadas em cerca de 20 grupos principais conforme a TAB. $1^{10}$. 
Tabela 1 - Classificação das Borrachas.

\begin{tabular}{cl}
\hline Sigla & \multicolumn{1}{c}{ Descrição } \\
\hline CR & Policloropreno (Neoprene $\AA$ da DuPont) \\
EPR & Borracha de Etileno-Propileno \\
IR & Borracha Butílica - Poliisobutileno \\
NBR & Poliisopreno \\
NR & Borracha Nitrílica (Acrilonitrila-Butadieno) \\
SBR & Borracha Natural \\
BR & Borracha de Estireno-Butadieno \\
EPDM & Bolibutadieno \\
ACM, AEM & Borracha de Etileno-Propileno-Dieno \\
ECO, CO & Borrachas Acrílicas \\
CSM & Polietileno Cloro Sulfonado (Hypalon da DuPont) \\
CFM, FPM, FKM & Borrachas Fluoradas (Viton da DuPont) \\
T & Polissulfetos (Thiokol) \\
PUR, AU, EU, PU & Borrachas de Poliuretano \\
MVQ, Si & Borrachas de Silicone \\
FMVQ & Borracha de Silicone Fluorada \\
HNBR & Borracha Nitrílica Hidrogenada \\
TPE, TPR, TR & Borrachas Termoplásticas \\
GPO & Elastômero de Óxido de Propeno \\
\hline Fonte:Panoramado Setor de Borracha
\end{tabular}

O termo borracha aplica-se tanto às matérias-primas como aos artefatos com ela produzidos. Segundo a norma ASTM D-1566 ${ }^{11}$ (American Society for Testing and Materials), a borracha é definida como um material capaz de recuperar-se de grandes deformações, de maneira rápida, sendo essencialmente insolúvel, mas que pode inchar em determinados solventes (como por exemplo, benzeno ou tolueno e metil-etil-cetona $)^{8}$. 


\subsubsection{História da Borracha}

A borracha ficou conhecida na Europa, desde o descobrimento da América do Sul. O primeiro europeu a mencionar uma goma elástica foi Pietro Martire d'Anghiera (1457-1526), que em seu livro De Orbe Novo (publicado em latim, 1513), descreveu que os índios brincavam com bolas que pulavam e eram feitas com a seiva leitosa de certa árvore ${ }^{12}$.

O engenheiro francês Condamine, em 1735, estudou a borracha da Guiana Francesa e concluiu que era "uma espécie de óleo resinoso condensado". O primeiro emprego da borracha foi como apagador, proposto por Magellan. $\mathrm{O}$ inglês Priestley difundiu este uso e a borracha recebeu, nesta língua, o nome de Índia Rubber, que significa Raspador da Índia ${ }^{8}$ (Índia, indicando a procedência e Rubber, a utilidade, ou seja, apagador, raspador). Os franceses a conhecem como Caoutchouc (origem indígena - árvore que chora) e os espanhóis, como caucho (mesma origem). Italianos e alemães chamam-na de goma e gummi, respectivamente ${ }^{4}$.

Macquer, retomando os trabalhos de Condamine, indicou o modo de fabricação de tubos flexíveis de borracha. Em 1820, um industrial inglês chamado Nadier, fabricou fios de borracha e utilizou-a como acessórios de vestuário. Desta forma, começou a reinar na América a "febre" da borracha, como os calçados impermeáveis dos índios, produção de tecidos impermeáveis e botas de neve.

Em 1832, foi criada a fábrica de Rosburg, que utilizava artefatos de borracha natural, não vulcanizada, que sofriam sob a influência do frio, tornandoos quebradiços, além do inconveniente de aderirem uns aos outros, quando expostos ao calor. Isto resultou no desinteresse dos consumidores ${ }^{8}$.

Charles Goodyear, em 1839-1840, após tentar desenvolver um processo para melhorar a qualidade da borracha (incorporando ácido nítrico $\mathrm{HNO}_{3}$ ) e ser levado à ruína, descobriu acidentalmente que, adicionando-se enxofre à borracha, sob aquecimento, obtinha-se uma goma elástica que não esfarelava e nem colava. Este processo foi denominado "vulcanização" 8,12. 0 termo tem origem na mitologia romana (Vulcano, Deus do fogo) e é usado para descrever o processo através do qual a borracha reage com enxofre, para produzir uma rede de ligações cruzadas e artefatos de forma fixa, não mais moldável, porém ainda flexível e elástico ${ }^{13}$. 
Thomas Hancock, em 1842, a partir de borracha vulcanizada de Goodyear, pesquisou e encontrou o segredo da vulcanização, fazendo fortuna.

Em 1845, Thomson inventou o pneumático, a câmara de ar e adicionou banda de rodagem com liga metálica (ferro). Em 1850, já se fabricavam brinquedos de borracha, bolas ocas e maciças (para uso em golfe e tênis). A invenção do velocípede por Michaux, em 1869, conduziu à invenção da borracha maciça, depois da borracha oca e, por último, à reinvenção do pneu, pois a invenção de Thomson havia caído no esquecimento.

Entre 1879 e 1882, foi realizada a polimerização do isopreno, obtendose produtos de propriedades semelhantes à borracha natural. Michelin, em 1895, adaptou o pneu aos automóveis e, desde então, a borracha passou a ocupar um lugar preponderante no mercado mundial ${ }^{8}$.

Os russos e alemães foram os pioneiros nos trabalhos de síntese da borracha, mas os produtos obtidos não suportaram a concorrência da borracha natural, possuindo desempenho inferior. Somente com a Primeira Guerra Mundial, a Alemanha, forçada pelas circunstâncias, teve que desenvolver a industrialização do seu produto sintético. Foi o marco inicial do desenvolvimento da indústria de borracha sintética, no mundo ${ }^{14}$.

\subsubsection{Compostos de Borracha}

Um composto de borracha pode ser definido como a combinação de elastômeros e aditivos, para obter uma mistura que proporcione as propriedades físicas e químicas necessárias ao produto final. Na formulação de um composto de borracha, utilizam-se vários ingredientes, cujo número pode ser superior a dez. Cada um deles possui uma função específica e um correspondente impacto nas propriedades, na processabilidade e no preço do composto.

Os ingredientes que integram uma formulação podem ser classificados como: elastômeros, agentes de vulcanização, aceleradores, ativadores, retardadores, antidegradantes (agentes de proteção), auxiliares de processo, plastificantes, pigmentos e outros ingredientes especiais.

Numa fórmula de composto de borracha, a quantidade de ingrediente é expressa em phr (partes por cem de borracha - parts for hundred of rubber) e a ordenação recomendada dos ingredientes da fórmula é a mesma daquela utilizada no processo de elaboração da mistura ${ }^{7}$. 


\subsubsection{Vulcanização da Borracha}

A vulcanização pode ser definida como a passagem do elastômero (macromolécula polimérica formada por hidrocarbonetos naturais ou sintéticos), de seu estado original, predominantemente plástico a outro elástico, de características definidas, estáveis e de grande resistência a agentes físicos e químicos. Na vulcanização, as macromoléculas são ligadas umas às outras, para formar uma rede tridimensional de macromoléculas com menos mobilidade e movimento, por meio de ligações cruzadas entre elas (reticulação). Estas ligações ocorrem normalmente entre dois átomos de carbono, pertencentes a diferentes cadeias moleculares, algumas vezes sem nenhum outro átomo (ou átomos) entre eles. Outras vezes, podem ocorrer com um átomo (ou átomos), não necessariamente de carbono, entre eles. A velocidade com que a vulcanização acontece é diretamente proporcional à quantidade de calor e energia aplicada, já que a maioria destes processos é dependente do calor. Portanto, quanto mais alta for a temperatura, menor será o tempo de vulcanização ${ }^{7}$.

Para realizá-la, é necessário adicionar agentes específicos associados a processos, que podem ser contínuos ou descontínuos.

\subsubsection{Agentes de Vulcanização}

Os agentes de vulcanização são substâncias que promovem ligações cruzadas entre as macromoléculas dos elastômeros. De acordo com o tipo químico, emprega-se determinado agente de vulcanização ou também chamado agente de cura. Eles são responsáveis pela grande transformação que ocorre com o elastômero, passando do estado plástico para elástico, de solúvel para insolúvel etc.

Há vários agentes de vulcanização, como: enxofre (agente original usado por Goodyear e ainda o mais comum em uso na indústria da borracha); doadores de enxofre (certas substâncias químicas que podem substituir parcial ou totalmente o enxofre, melhorando a resistência ao calor e envelhecimento); agentes não sulfurosos (óxidos metálicos - uso em elastômeros que possuem um grupo ou átomo ativo na cadeia molecular; peróxidos orgânicos - empregados em elastômeros que não possuem insaturações, nem grupos funcionais reativos, como as siliconas e o polietileno-propileno; substâncias bifuncionais, como resinas epóxi, resinas fenólicas, quinonadioximas) $)^{4,7}$. 


\subsubsection{Processos de Vulcanização}

Os processos de vulcanização podem ser classificados em descontínuos e contínuos e são descritos a seguir.

\subsection{Processos de Vulcanização Descontínuos}

Os processos de vulcanização descontínuos são bastante utilizados para a vulcanização de extrudados (processo de conformação de materiais feito por meio de um equipamento chamado de extrusora, que força sua passagem através de uma matriz para conformá-lo) de pequenas dimensões ou, ainda, de peças em que é preciso vulcanizar em moldes. Os processos de vulcanização descontínuos são7:

a) Vulcanização com vapor direto sob pressão (autoclave) - O material a ser vulcanizado é submetido á ação direta de vapor saturado em autoclaves que trabalham na faixa de pressão de 3 a $6 \mathrm{kgf} / \mathrm{cm}^{2}\left(145^{\circ} \mathrm{C}-165^{\circ} \mathrm{C}\right)$. Atuando como gás inerte, o vapor saturado oferece condições de boa transferência de calor. Por este processo são vulcanizados tubos, mangueiras, fios e cabos além de artigos trafilados em geral.

b) Vulcanização com ar quente - A vulcanização é aberta (sem pressão) em ar quente, e é geralmente efetuada em estufas com circulação de ar. Em virtude da pequena condutividade térmica do ar, o sistema não é muito eficiente. Por este processo são vulcanizados artefatos de pequena espessura, tais como: botas, galochas e certos tipos de calçados

c) Vulcanização por água quente - Este processo pode ser efetuado ao ar livre sem pressão ou sob baixa pressão é indicado para revestimentos de artigos de grande porte (containers). Consiste em preencher o tanque revestido com uma camada de composto de borracha, com água salgada ou com cloreto de cálcio $\left(\mathrm{CaCl}_{2}\right)$, o que permite, por borbulhamento de vapor, atingir-se uma temperatura de $105^{\circ} \mathrm{C}$. 


\subsection{Processos de Vulcanização Contínuos}

Inclui técnicas para curar um produto previamente conformado (préformado). Os processos de vulcanização contínuos permitem a produção de perfis em grande escala, com maior rentabilidade para a linha de extrusão e podem ser classificados $\mathrm{em}^{7}$ :

a) Vulcanização em ar quente - Este processo consiste em conformar o composto previamente como por exemplo, em uma extrusora, e desta forma entra em um túnel de ar quente, sem pressão

b) Vulcanização em banhos líquidos (ou banhos de sais) - Este processo envolve o uso de banhos líquidos quentes, para os artefatos que são extrudados. Eles são rapidamente vulcanizados, em temperaturas de $200^{\circ} \mathrm{C}$ a $300^{\circ} \mathrm{C}$. Os materiais mais indicados para a obtenção dos banhos são: nitrato de potássio $\left(\mathrm{KNO}_{3}\right)$ concentrado $53 \%$, nitrato de sódio $\left(\mathrm{NaNO}_{3}\right)$ concentrado $7 \%$ e nitrito de sódio $\left(\mathrm{NaNO}_{2}\right)$ concentrado $40 \%$

c) Vulcanização em leitos fluidizados - Consiste de um recipiente com fundo em cerâmica porosa, preenchido com pequenas esferas de vidro, no qual aplica-se uma corrente de ar altamente aquecida, pela passagem em resistências elétricas, acarretando um movimento permanente das esferas (fluidização). É empregado na produção contínua de perfis extrudados com alma de metal (menor risco de distender ou romper). A condutividade calórica das esferas de vidro é baixa, sendo difícil atingir temperaturas de vulcanização superiores a $190^{\circ} \mathrm{C}$ $200^{\circ} \mathrm{C}$

d) Vulcanização em tubos de vapor - Consiste na passagem de um perfil extrudado através de um tubo de $150 \mathrm{~m}$ a $200 \mathrm{~m}$, por onde circula vapor sob pressão $\left(15 \mathrm{kgf} / \mathrm{cm}^{2}\right)$ e alta temperatura $\left(200^{\circ} \mathrm{C}\right)$, controlando-se a velocidade (pode ultrapassar $200 \mathrm{~m} / \mathrm{min}$ ) de passagem do perfil, pode-se controlar a vulcanização

e) Vulcanização por rotocura - Este processo é indicado para produtos calandrados, tais como correias transportadoras. A máquina consiste de um tambor rotativo de grande diâmetro, sobre o qual atua uma correia sem fim, que é pressionada contra a parede do tambor (com aquecimento interno). O tambor é aquecido (com vapor ou fluido térmico, entre $130^{\circ} \mathrm{C}$ e $160^{\circ} \mathrm{C}$ ) O material é 
colocado entre a parede do tambor quente e a correia., e a vulcanização ocorre por ação do calor e sob compressão da correia

f) Vulcanização por embainhamento de chumbo - ocorre na presença de vapor, após o material extrudado receber uma bainha de chumbo, aplicada por meio de pressão hidráulica ou extrusão

g) Vulcanização a frio - Este processo é utilizado para artefatos de pequena espessura, o material é imerso em solução ou exposto em vapor de monocloreto de enxofre $\left(\mathrm{S}_{2} \mathrm{Cl}_{2}\right)$

h) Vulcanização por radiação de alta energia - esta técnica usa raios gama do ${ }^{60} \mathrm{Co}$ ou infravermelho e é muito utilizado para borrachas de silicone. Não gera nem aplica qualquer tipo de calor no composto

i) Vulcanização por microondas - apresenta como principal vantagem, o aquecimento rápido e uniforme do material; o controle de temperatura é muito eficaz, pois o calor é todo concentrado no artefato. Foi desenvolvido com o objetivo de eliminar o problema de transmissão de calor. O material é colocado em um campo eletromagnético de alta freqüência, ficando uniformemente aquecido através de toda a sua massa.

\subsubsection{Devulcanização e Recuperação da Borracha}

O processo reversível da vulcanização da borracha, chamado de devulcanização, tem sido amplamente estudado, com o objetivo de romper as ligações cruzadas carbono-enxofre (C-S) e enxofre-enxofre (S-S) ${ }^{1}$. A borracha devulcanizada pode servir como substituta da borracha virgem, em alguns casos, na formulação de um composto, com relação às propriedades e custo de manufatura. A borracha devulcanizada pode ser revulcanizada com ou sem o uso de outros compostos ${ }^{15,16}$.

A estrutura molecular da borracha devulcanizada é diferente da estrutura da borracha não vulcanizada (FIG.2). Devido à elevada distribuição do peso molecular, o produto revulcanizado deverá ter propriedades mecânicas mais baixas em comparação com o produto de borracha virgem. Além disso, as condições de revulcanização devem também influenciar a mudança na massa molecular ${ }^{17}$. 


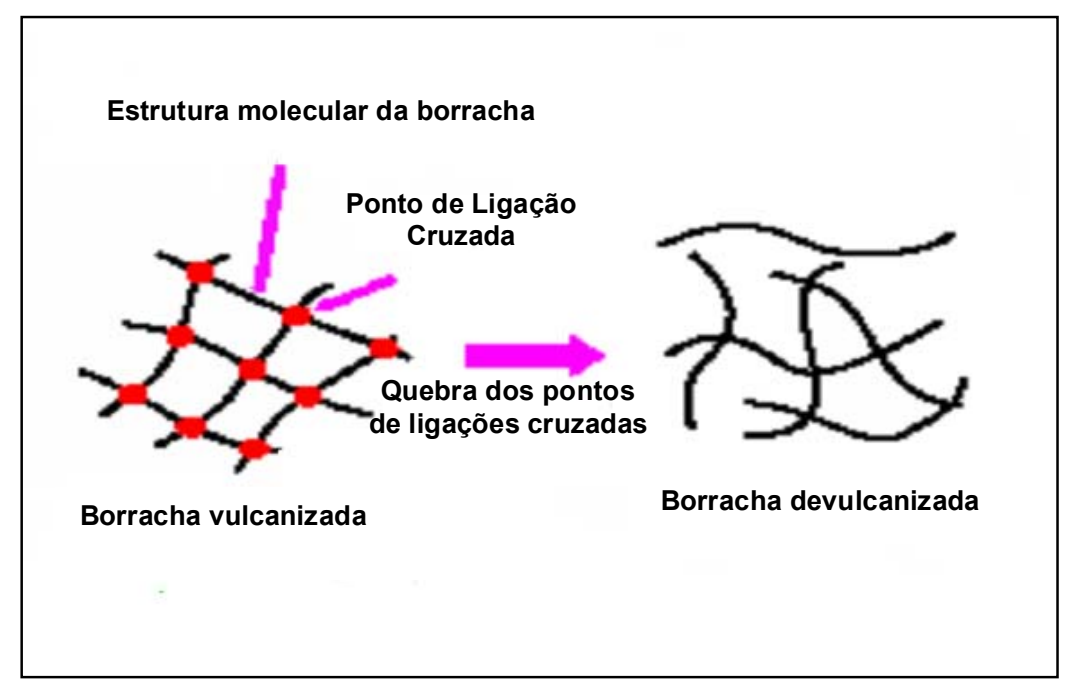

FIGURA 2 - Estrutura molecular da borracha vulcanizada e devulcanizada.

No processo de recuperação, a cadeia macromolecular da borracha é transformada em pequenos fragmentos de baixa massa molecular, de maneira que ela possa ser facilmente misturada com borracha virgem, na formação do composto ${ }^{1}$.

Os métodos de recuperação/reciclagem e devulcanização de borrachas podem ser classificados basicamente em três grupos: processos químicos, processos biológicos e processos físicos.

\subsubsection{Processos Químicos}

A utilização de produtos químicos na recuperação/reciclagem de borrachas é feita, principalmente, com reatores de alta pressão, solventes específicos e altas temperaturas, que ativam a cinética das reações.

Atualmente, estes processos são realizados com a adição de ingredientes específicos, um segundo polímero e reações particulares, em cilindros abertos e baixas temperaturas, mas os resultados são muito variados.

Os tipos de processos químicos são: bissulfetos orgânicos e mercaptanas (são líquidos de odor desagradável e classes de compostos em que um hidrogênio de $\mathrm{H}_{2} \mathrm{~S}$ - Sulfeto de Hidrogênio - é substituído por um radical orgânico), compostos inorgânicos, misturas químicas, degradação química e pirólise (decomposição química por calor, na ausência de oxigênio, com balanço energético positivo, ou seja, produz mais energia do que consome). A maioria das 
indústrias de recuperação de borracha usa agentes químicos de recuperação, mas eles são bastante tóxicos e prejudiciais ao meio ambiente ${ }^{1}$.

\subsubsection{Processos Biológicos}

A devulcanização biológica geralmente é atrativa, por causa da sua alta seletividade. Entretanto, é necessário muito esforço para encontrar um meio de cultura conveniente e obter-se um processo de alta conversão. Nestes processos seletivos, as ligações químicas das borrachas vulcanizadas são quebradas e o enxofre removido por meio de biotratamento com bactérias. Algumas delas têm sido utilizadas, para devulcanizar NR, SBR e BR, como Nacardia, Thiobacillus e Mycolata, sem causar significativa degradação do hidrocarboneto polimérico. Em literatura, estes métodos são citados como de baixo rendimento de devulcanização, atacando somente a superfície das amostras e ainda estão longe de serem aplicados industrialmente ${ }^{17,18}$.

\subsubsection{Processos Físicos}

Nestes processos, a rede tridimensional do polímero reticulado rompe na presença de diferentes fontes de energia. A seguir, são citados os principais.

\subsection{Processo Mecânico}

No processo de recuperação mecânica, a borracha é cisalhada por meio de misturadores abertos (dois rolos) e ocorre a decomposição química, diminuindo sua massa molecular. São utilizados aditivos, reduzindo os resíduos a grãos, que são processados em diferentes proporções, com resina virgem, formando uma massa homogênea. Os materiais resultantes são empregados apenas como carga inerte, apesar da boa miscibilidade com a borracha virgem¹.

\subsection{Processo Termomecânico}

Este processo envolve a degradação da rede de ligações da borracha vulcanizada. $\mathrm{O}$ vulcanizado é colocado num solvente apropriado para ser inchado e então transferido para um cilindro de rolos para transformá-lo num pó fino (aproximadamente $20 \mu \mathrm{m}$ de diâmetro). Este pó de borracha é revulcanizado com agentes de cura. Os produtos obtidos apresentam propriedades inferiores quando comparados ao produto vulcanizado original ${ }^{1}$. 


\subsection{Processo Criomecânico}

Neste processo de recuperação, as amostras de borracha vulcanizada são mergulhadas em nitrogênio liquido e transferidas para moinho de bolas, que reduz o tamanho do material a ser reciclado até a forma de pó. O tamanho das partículas é controlado pelo tempo de imersão no nitrogênio liquido e podem variar de 30 mesh a 100 mesh. As propriedades mecânicas do composto são melhoradas pelo maior grau de refino do reciclado e o pó obtido também é usado como carga inerte ${ }^{1}$.

\subsection{Processo de Ultra-som}

A freqüência do som é classificada em relação à sensibilidade do ouvido humano, que compreende a faixa de $16 \mathrm{~Hz}$ a $16 \mathrm{KHz}$. A freqüência característica de ultra-som, em geral, está no intervalo de $16 \mathrm{KHz}$ a $1 \mathrm{MHz}$. Sendo que freqüências de $1 \mathrm{MHz}$ a $10 \mathrm{MHz}$ correspondem à região de alta freqüência ${ }^{19}$.

Em determinados níveis, as ondas emitidas, em presença de pressão e aquecimento, podem quebrar a rede de ligações cruzadas da borracha vulcanizada, porém podem causar também uma degradação significativa das cadeias poliméricas ${ }^{1}$.

A tecnologia de devulcanização empregada neste processo é, na verdade, a combinação entre a extrusão e aplicação de energia de ultra-som. Neste caso, é usado um equipamento que gera energia e uma extrusora, que empurra e puxa a borracha (mastigação mecânica). A extrusão da amostra pode ser feita antes ou após a aplicação de ultra-som. A etapa final, em qualquer um dos casos, é a passagem da amostra por um banho de refrigeração. A combinação entre aquecimento, pressão e mastigação é suficiente para permitir um variado grau de devulcanização ${ }^{16,20}$.

\subsection{Processo de Microondas}

As microondas são ondas eletromagnéticas não-ionizantes, com freqüências no intervalo de $300 \mathrm{MHz}$ a $300 \mathrm{GHz}$. A sua classificação inclui, ainda, três bandas: a freqüência ultra-alta (UHF - Ultra High Frequency: $300 \mathrm{MHz}$ a $3 \mathrm{GHz}$ ), a freqüência super-alta ( $\mathrm{SHF}$ - Super High Frequency: $3 \mathrm{GHz}$ a $30 \mathrm{GHz}$ ) e a freqüência extremamente alta (EHF - Extremely High Frequency: $30 \mathrm{GHz}$ a $300 \mathrm{GHz})^{21}$. 
Este intervalo é usado em sistemas de comunicação TV-satélite, navegação, Biologia, Química e Medicina. As freqüências de trabalho de $915 \mathrm{MHz}$, 2.450MHz, $5.800 \mathrm{MHz}$ e $22.125 \mathrm{MHz}$ foram aceitas por um acordo internacional para uso em instalações de microondas, científicas e industriais ${ }^{22}$. Atualmente, 2.450MHz é a freqüência mais utilizada para forno de microondas caseiro que foi inventado por Spencer, em 1949, e têm sido muito empregadas em outras áreas, como: secagem de materiais (poliméricos, cerâmicos e refratários); aceleração do processo de cura do concreto; sínteses químicas; esterilização de materiais; craqueamento de petróleos pesados e regeneração de óleos usados ${ }^{21,22} 23$.

Provavelmente, este é o processo mais eficaz para realizar a reciclagem de reticulados, pois desmonta esta rede tridimensional, sem depolimerização do polímero e permite uma nova reticulação (ou vulcanização), com propriedades equivalentes ao composto original. Neste caso, o reciclado retorna como carga ativa, sendo utilizada energia de microondas numa freqüência específica, para dereticulação do polímero ${ }^{1}$.

O processamento de materiais por microondas proporciona, ainda, várias vantagens em relação aos métodos de aquecimento convencionais ${ }^{21,23}$, como:

- Aquecimento - sem contato, mais rápido, seletivo, mais uniforme e que se inicia de dentro para fora do material

- Transferência de energia, não de calor

- Início e parada rápidos

- Maior nível de segurança e automação

- Economia de energia elétrica

- Processo físico ambientalmente limpo, pois não utiliza produtos químicos

- Utilização de espaços menores.

O mecanismo de aquecimento por microondas é aquele no qual a energia é absorvida pela matéria e transformada em energia cinética e potencial das moléculas, sendo as partes mais internas aquecidas primeiramente ${ }^{24}$.

Um dos aspectos mais interessantes relacionados com este tipo de radiação é o aquecimento seletivo. Diferente do forno elétrico ou de combustão, onde todos os materiais que estão no interior do forno sofrem aquecimento, no 
forno de microondas, o aquecimento depende do material contido no seu interior. Assim, é comum observar que partes do recipiente, que não estão em contato direto com o material recém aquecido com microondas, continuam na temperatura próxima à do ambiente. Desta maneira, o processo é baseado na conversão direta de energia dentro do material que está sendo tratado e a necessidade de aquecer o recipiente, como em um forno convencional, é eliminada. Conseqüentemente, a velocidade dos processos pode ser mais alta.

Como os materiais reagem diferentemente diante da energia de microondas, podem ser classificados de acordo com seu comportamento em: condutores, isolantes e dielétricos. A família dos condutores é basicamente formada pelos metais, que refletem as microondas (assim como um espelho reflete a luz), não havendo penetração destas ondas. Os isolantes transmitem as microondas com pouco efeito ou até mesmo nenhum efeito de aquecimento, semelhante à passagem da luz por um vidro. Os dielétricos são a maioria dos materiais e têm propriedades entre os isolantes e os condutores. As microondas passam através deles, como nos isolantes, mas absorvem energia, resultando no aquecimento do dielétrico ${ }^{25}$.

Do ponto de vista clássico, o aquecimento de um material por microondas ocorre por meio da interação desta onda eletromagnética com o dipolo elétrico da molécula. Quando um campo elétrico é aplicado, as moléculas que possuem momento de dipolo elétrico tendem a se alinhar com ele. Por sua vez, quando este campo é removido, as moléculas tendem a voltar para o estado anterior (menos alinhado), dissipando a energia absorvida na forma de calor. Se um material possui maior valor de constante dielétrica, então maior quantidade de energia pode, a princípio, ser armazenada. Em um campo que alterna as fases (como em uma onda eletromagnética), a orientação molecular varia ciclicamente ${ }^{22,}$ 26, 27 (FIG. 3). 


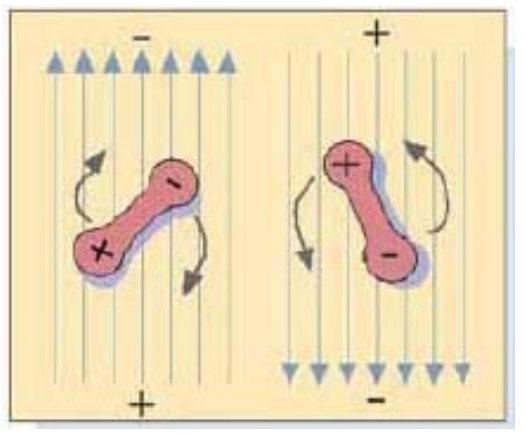

Figura 3 - Movimento rotacional cíclico das moléculas de um material submetido a um campo elétrico alternado.

No caso de um forno de microondas que opera com freqüência de $2.450 \mathrm{MHz}$, isto significa dizer que a direção do campo elétrico muda 2,45 $\times 10^{9}$ vezes por segundo. Portanto, tão logo as moléculas polares do material sofram certo alinhamento parcial, a direção do campo reverte e as moléculas são realinhadas. O alinhamento e realinhamento das moléculas com elevada freqüência produzem grande quantidade de calor, levando ao aquecimento do material ${ }^{25}$. Além disso, a penetração da radiação eletromagnética é inversamente proporcional à sua freqüência.

\subsection{Policloropreno}

O Neoprene $®$, marca registrada da DuPont, é o nome genérico do polímero de cloropreno (2-cloro-1,3-butadieno). O primeiro Neoprene $₫$ foi vendido em 1932, sob o nome de "DuPrene". À medida que a sua tecnologia de polimerização era aperfeiçoada, foram criados outros tipos com melhores propriedades $^{3,28,29}$.

Existem atualmente diversos fabricantes, que produzem vários tipos desta borracha, com características específicas, como: Viscosidade Mooney (fornece uma avaliação indireta do peso molecular de elastômeros e está relacionada com a processabilidade) ${ }^{30}$, e cristalização (que provoca uma espécie de auto-vulcanização muito lenta, quando a borracha virgem fica estocada por muito tempo $)^{3}$. 


\subsubsection{Preparação do Cloropreno}

O cloropreno pode ser obtido por meio de dois processos básicos: acetileno e butadieno, descritos a seguir:

a) Processo Acetileno

Neste processo, o acetileno $\left(\mathrm{C}_{2} \mathrm{H}_{2}\right)$ é a principal matéria-prima utilizada na manufatura do cloropreno. As reações químicas básicas são as seguintes:

$$
\begin{aligned}
& \mathrm{HC} \equiv \underset{\mathrm{H}}{\mathrm{CH}} \stackrel{\mathrm{CuCl}}{\longrightarrow} \mathrm{HC} \equiv \mathrm{C}-\mathrm{CH}=\mathrm{CH}_{2} \text { (mononinilacetileno) } \\
& \mathrm{HC} \equiv \mathrm{C}-\mathrm{CH}=\mathrm{CH}_{2}+\mathrm{HCl} \stackrel{\text { CuCl }}{\longrightarrow}-\mathrm{H}_{2} \mathrm{C}=\underset{\mathrm{Cl}}{\mathrm{C}}-\mathrm{CH}=\mathrm{CH}_{2} \text { (cloropreno) }
\end{aligned}
$$

O acetileno é dimerizado em monovinilacetileno (um gás com temperatura de ebulição de $5^{\circ} \mathrm{C}$ ) na presença de uma solução catalisadora aquosa de cloreto cuproso. O monovinilacetileno reage depois com o gás clorídrico para formar o monômero de cloropreno, um liquido com ponto de ebulição de $59^{\circ} \mathrm{C}$.

b) Processo Butadieno

Atualmente, a maior parte dos cloroprenos é produzida por meio deste processo, no qual o gás clorídrico $\left(\mathrm{Cl}_{2}\right)$ reage com o butadieno, na presença de um catalisador, conforme as reações sucessivas:

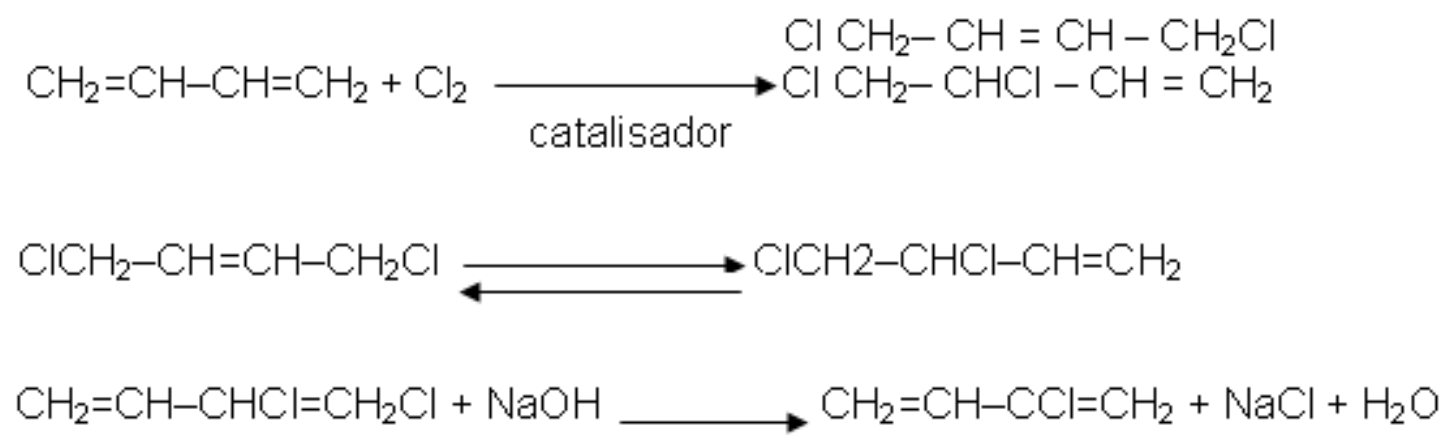

Após a sua depuração ou fracionamento, o monômero de cloropreno é emulsificado em água e polimerizado. O progresso da polimerização é controlado pela variação da densidade da emulsão ${ }^{31}$. 


\subsubsection{Tipos de Policloropreno}

O Neoprene $®$ pode ser classificado em três tipos: uso geral, adesivo e látex. Os mais importantes são os tipos de uso geral, usados particularmente em produtos moldados e extrudados, tais como: mangueiras, correias, fios e cabos, saltos e solas de sapatos, aro de pneus, revestimentos de tecidos e gaxetas ${ }^{29}$.

Todos os tipos de uso geral podem ser classificados, ainda em: tipo " $G$ " (cor âmbar); tipo "W" (cor branca para prata acinzentada); e o tipo "T" (cor creme a âmbar claro). A densidade de todos os tipos está entre $1,23 \mathrm{~g} / \mathrm{cm}^{3}$ a $1,25 \mathrm{~g} / \mathrm{cm}^{3}$, em $24^{\circ} \mathrm{C}$ a $25^{\circ} \mathrm{C}^{31}$.

Os Neoprenes ${ }^{\circledR}$ vulcanizados obedecem às normas ASTM D-2000 ${ }^{32} \mathrm{e}$ segundo o código BC de material. O Neoprene ${ }^{\circledR}$ pode ser combinado para produzir artefatos vulcanizados práticos, que têm as seguintes propriedades, mostradas na TAB.2.

TABELA 2 - Propriedades do Neoprene®.

\begin{tabular}{c|c}
\hline Propriedade & Especificação \\
\hline Dureza & 20 a 90 shore A \\
\hline Resistência a Tração & 4000 psi mín. \\
\hline Alongamento & $900 \%$ mín \\
\hline DPC & $>10 \%$ \\
\hline
\end{tabular}

DPC - Deformação Permanente à Compressão.

Naturalmente, nenhum composto refletirá os extremos das escalas mostradas na tabela acima e cada tipo de Neoprene ${ }^{\circledR}$ de uso geral possui características diferentes, tais como ${ }^{31}$.

- Tipos "G" - (Neoprenes $®$ GN, GNA e GRT): foram vendidos pela primeira vez em 1939, sendo hoje o tipo de Neoprene ${ }^{\circledR}$ mais antigo. Eles possuem melhor distribuição do peso molecular do que os da família "W" e "T". Necessitam ser peptizados com ingredientes químicos ou por intensa mastigação mecânica, facilitando os processamentos subseqüentes, além de proporcionar incorporações de maiores teores de cargas. A peptização diminui o nervo do composto oferecendo maior facilidade de extrusão, calandragem e friccionamento 
sobre fibras têxteis normalmente usadas na fabricação de mangueiras, correias transportadoras ou de transmissão, minimizando problemas de moldagem e conformação. Normalmente os Neprenes ${ }^{\circledR}$ deste tipo não necessitam de aceleradores orgânicos e possuem boas propriedades, tais como: alta tensão de ruptura e rasgamento, alto alongamento, resistência à fadiga por flexão dinâmica e baixa DPC (Deformação Permanente à Compressão).

- Tipos "W" - (Neoprenes® W, WHV, WX, WRT, WD e WB): foram postos no mercado em 1949. Comparando-se com as características do tipo " $G$ ", pode-se dizer que o Neoprene® tipo "W" oferece maior estabilidade de estocagem do polímero cru, mistura mais fácil e rápida, não necessitando de peptização química ou extensos trabalhos mecânicos. Requerem aceleradores orgânicos para promover boa taxa de vulcanização, oferecem artigos vulcanizados de excelente qualidade e baixa DPC. Aceitam altos teores de carga e proporcionam ótimas propriedades de tensão de ruptura, não mancham, podendo-se fabricar artigos de cores claras. Possuem rápida velocidade de vulcanização e normalmente necessitam de etileno tiurea ( $\mathrm{Na} 22$ ou ETU) como acelerador de vulcanização, além de não conterem modificadores de estrutura polimérica.

- Tipos "T" - (Neoprenes $®$ TW, TW-100, TRT); foram postos no mercado em 1952. Combinam as propriedades do Tipo "W" e oferecem elevada tensão de ruptura e rasgamento e rápida velocidade de vulcanização, com propriedades análogas ao do tipo "W". Contudo, oferecem processamento de mistura mais fácil e rápido, bem como artigos extrudados ou calandrados com superfície lisa e brilhante. Necessitam de aceleradores orgânicos para promover a vulcanização e não contêm modificadores na estrutura polimérica. ${ }^{28,29}$.

As diferenças básicas dos Neoprenes ${ }^{\circledR}$ dos tipos "G", "W" e "T" são apresentadas na TAB. $3^{28}$. 
TABELA 3 - Diferenças básicas entre os tipos de Neoprene®.

\begin{tabular}{|c|c|c|c|}
\hline & Tipo “G” & Tipo “W" & Tipo “T” \\
\hline $\begin{array}{l}\text { Elastômero } \\
\text { não vulcanizado }\end{array}$ & $\begin{array}{l}\text { - Estabilidade de } \\
\text { estocagem limitada } \\
\text { - Necessita de } \\
\text { peptizante no início da } \\
\text { mastigação } \\
\text { - Cura rápida devendo- } \\
\text { se observar a } \\
\text { temperatura na mistura } \\
\text { devido à segurança à } \\
\text { pré-cura } \\
\text { - Não necessita de } \\
\text { aceleradores orgânicos } \\
\text { - Excelente adesão }\end{array}$ & $\begin{array}{l}\text { - Ótima estabilidade } \\
\text { de estocagem. } \\
\text {-Não necessita de } \\
\text { peptizante. } \\
\text { - Necessita de } \\
\text { aceleradores } \\
\text { orgânicos. }\end{array}$ & $\begin{array}{l}\text { - Ótima estabilidade em } \\
\text { estocagem } \\
\text { - Menor Nervo* } \\
\text { - Não necessita de } \\
\text { peptizante } \\
\text { - Ótimas propriedades } \\
\text { para extrusão e } \\
\text { calandragem } \\
\text { - Necessita de } \\
\text { aceleradores orgânicos }\end{array}$ \\
\hline $\begin{array}{l}\text { Elastômero } \\
\text { vulcanizado }\end{array}$ & $\begin{array}{l}\text { - } \quad \text { Alta tensão de } \\
\text { ruptura e rasgamento } \\
\text { - Ótima resistência à } \\
\text { flexão dinâmica } \\
\text { - Alta resiliência }\end{array}$ & $\begin{array}{l}\text { - } \text { Baixa DPC } \\
\text { - } \quad \text { Boas propriedades } \\
\text { de resistência ao calor } \\
\text { - } \quad \text { Altos módulos }\end{array}$ & $\begin{array}{l}\text { - Propriedades do } \\
\text { vulcanizado, similar ao tipo } \\
\text { W } \\
\text { - Menor Nervo* } \\
\text { - Artigos calandrados e } \\
\text { extrudados com } \\
\text { superfícies mais lisas e } \\
\text { brilhantes }\end{array}$ \\
\hline
\end{tabular}

- $\quad$ termo usado na indústria para designar borracha de difícil mastigação em cilindro aberto. 


\section{OBJETIVOS}

O objetivo principal deste trabalho foi estudar o processo de devulcanização de borracha de cloropreno $(C R)$, aplicando-se altas energias eletromagnéticas na faixa de microondas. Esta técnica foi utilizada como uma alternativa na reciclagem (recuperação) para este tipo de material, visando a preservação do meio ambiente.

Para este fim, foi desenvolvida uma formulação básica de $C R$, empregada na indústria automobilística e analisadas as propriedades físicoquímicas das amostras, antes e após as irradiações, verificando-se a confiabilidade do método neste tipo de borracha.

Neste trabalho, o propósito foi, ainda, a obtenção de materiais básicos que permitissem uma nova reticulação (ou vulcanização), no qual o reciclado retornasse como carga ativa e não como carga inerte, para fabricação de artefatos. 


\section{REVISÃO DA LITERATURA}

Em literatura, foram relatados trabalhos sobre recuperação e reciclagem de borrachas, utilizando-se diversas metodologias de devulcanização, citados a seguir.

Novotny et al., em $1978^{5}$, utilizaram energia de microondas com freqüência de $915 \mathrm{MHz}$ a $2.450 \mathrm{MHz}$, para devulcanizar amostras de EPDM (sobras de mangueiras) fora de especificação e câmaras de pneus de borracha butílica, por meio da quebra de ligações entre átomos e moléculas. Estas condições, teoricamente, quebram ligações de enxofre e produzem um material que pode ser usado em compostos de borrachas virgens. No caso das amostras de EPDM, as variáveis analisadas foram: dose entre 41W.h/lb e 177W.h/lb $(1 \mathrm{lb}=453,592 \mathrm{~g})$; temperatura do elastômero entre $232^{\circ} \mathrm{C}$ e $427^{\circ} \mathrm{C}$ e freqüência de microondas. O método de devulcanização foi suficiente para romper substancialmente todas as ligações C-S e S-S, mas insuficiente para romper significativamente as ligações C-C. Este processo foi usado por muitos anos e posteriormente abandonado devido a problemas econômicos.

Anderson, em $1978^{33}$, relatou um método e equipamento de microondas, para devulcanização de artefatos fabricados com borrachas, como mangueiras, cintos e pneus. O dispositivo de microondas era constituído de um tubo rotativo transparente, disposto em determinado ângulo com a horizontal, por onde era inserido o material (restos de borracha), sob agitação contínua. 0 aquecimento uniforme ocorria em atmosfera controlada $\left(316^{\circ} \mathrm{C}\right.$ a $\left.382^{\circ} \mathrm{C}\right) \mathrm{e}$ causava a devulcanização destes materiais, que por sua vez possibilitava a sua mistura com borracha virgem.

Hayashi et al, em $1984^{34}$, descreveram um método para recuperação de borracha vulcanizada com o propósito de reuso, e mais particularmente, para produzir borracha recuperada em escala comercial, através da desulfurização dos refugos com energia de microondas. Nos experimentos, foi usada uma formulação de borracha de EPDM (aproximadamente 10kg), que depois de vulcanizada foi pulverizada, aquecida com microondas de $5 \mathrm{KW}$ de potência e freqüência de $2.450 \mathrm{MHz}\left(180^{\circ} \mathrm{C}\right.$ a $\left.300^{\circ} \mathrm{C}\right)$, durante $15 \mathrm{~min}$, reaquecida utilizando-se um forno elétrico de $1,5 \mathrm{~kW}$, por $30 \mathrm{~min}$ e resfriada com água (taxa de, no mínimo, $10^{\circ} \mathrm{C} / \mathrm{min}$, para que não houvesse oxidação do material durante 0 processo de 
desulfurização) e $\mathrm{CO}_{2}$ liquefeito. No caso de resfriamento com água, a adição era limitada o suficiente para resfriá-la até $150^{\circ} \mathrm{C}$ a $200^{\circ} \mathrm{C}$, a fim de não causar mudanças no peso do material. Após o processamento, as amostras foram misturadas em uma nova composição de borracha (aceleradores e enxofre), em diversas proporções e, em seguida, caracterizadas por meio de testes de dureza, tração, alongamento e DPC. Os resultados obtidos, para este tipo de borracha, mostraram pouca variação em suas propriedades físicas.

Tyler et al, em $1984^{35}$, relataram um processo para devulcanização via microondas, utilizando sobras de borracha, como: mangueiras de EPDM, rebarbas e câmaras de pneus de borracha butílica. O processo consistia em submeter amostras vulcanizadas com enxofre (que contêm grupos polares) a estas energias eletromagnéticas, gerando calor com temperaturas de até $260^{\circ} \mathrm{C}$. Em seguida, elas eram inseridas em uma extrusora e aquecidas entre $90^{\circ}$ a $125^{\circ} \mathrm{C}$ e, finalmente, reprocessadas em um cilindro de rolos. Estas amostras apresentaram propriedades físicas superiores àquelas que não foram processadas via extrusora.

Isayev e Chen $^{20}$, em 1994, relataram uma invenção que combinava o processamento de borrachas nitrílica hidrogenada - HNBR (hydrogenated nitrile rubber), fluorada - FCP (fluoro-carbon-polymer), SBR/NR e EVA, em uma de extrusora, acoplada a um equipamento de ultra-som $(15 \mathrm{kHz}$ a $50 \mathrm{kHz})$ sob pressão (com aquecimento opcional). O objetivo era realizar a quebra das ligações $\mathrm{C}-\mathrm{S}$, S-S, e se desejado, as de C-C dos elastômeros vulcanizados. Desta forma, a borracha vulcanizada tratada com esta metodologia ficava macia e o material podia ser reprocessado de maneira similar aos elastômeros não vulcanizados. Os autores citam que a aplicação desta metodologia para HNBR não só devulcanizou o material, mas também diminuiu o seu peso molecular, indicando a quebra de ligações C-C na cadeia polimérica. O mesmo foi relatado para amostras de SBR/NR.

Hunt e Hall ${ }^{36}$, em 1994, descreveram um processo de recuperação de restos de borracha (pneus automotivos), no qual impregnavam as amostras por $10 \mathrm{~h}$ a 13h, com diversos óleos essenciais (d-limonene, linalool, mycrene, entre outros) e, em seguida, as irradiava em um reator de microondas com pressão reduzida (reator a vácuo). O tempo de absorção variava de 30min até cerca de 20h, a pressão conveniente para absorção destes óleos estava entre 60psi e 100 psi, com temperaturas de $20^{\circ} \mathrm{C}$ a $80^{\circ} \mathrm{C}$. O reator de microondas operava com 
$5 \mathrm{~kW}$ de potência e freqüência de $2.000 \mathrm{MHz}$ a $3.000 \mathrm{MHz}$. Por meio deste método, todos os compostos voláteis foram removidos e as partículas de borracha desulfurizadas.

Wicks et $\mathrm{al}^{37}$, em 2002, citaram um processo para tratar e reciclar produtos de borracha, mais particularmente aqueles provenientes de banda de rodagem de pneus. Foram utilizadas microondas entre $85 \mathrm{~kW}$ a $850 \mathrm{~kW}$ de potência, com nitrogênio (para prevenir oxidação excessiva) e freqüência de 2.450 $\mathrm{MHz}$. As amostras empregadas possuíam 40mesh, massa entre $30 \mathrm{~g}$ a $300 \mathrm{~g}$ e atingiam temperaturas até $500^{\circ} \mathrm{C}$. No intervalo entre $360^{\circ} \mathrm{C}$ e $380^{\circ} \mathrm{C}$, foram obtidos os melhores resultados, nos quais as ligações C-S e S-S foram modificadas. A borracha devulcanizada possuía boas propriedades mecânicas, podendo ser usada em compostos para fabricação de bandas de rodagem e outras partes dos pneus.

Fillermans et $\mathrm{al}^{38}$, em 2002, descreveram o tratamento de restos de borracha vulcanizada (pneus), no qual utilizava-se a combinação dos processos biológico e físico com microondas, para devulcanização. Primeiramente, as amostras eram colocadas em contato com microrganismos thermophilicus e, em seguida, irradiadas com microondas. As bactérias eram incubadas com amostras de borracha (100g a $1.000 \mathrm{~g}$ e 40mesh de tamanho), para forçar a degradação metabólica das ligações do enxofre e seus compostos, por um período de $2 \mathrm{~h}$ a 72h. A bactéria era misturada à borracha na proporção de 10/40(v/v) a 30/40(v/v), sob agitação contínua em um bioreator, com temperatura de $50^{\circ} \mathrm{C}$ a $70^{\circ} \mathrm{C}$. Após a incubação, as amostras eram filtradas e lavadas com água destilada (e secas em ar, quando não submetidas imediatamente às microondas). As amostras foram irradiadas com estas energias eletromagnéticas, na potência de 850W e freqüência de $2.450 \mathrm{MHz}$, de $4 \mathrm{~min}$ a $60 \mathrm{~min}$, em atmosfera inerte de gás nitrogênio. As amostras tratadas foram misturadas na proporção de 12\% (não reportadas) a $20 \%$ com novos compostos de pneus. Foram realizadas testes comparativos com as amostras tratadas no bioreator, nas microondas, bioreator/microondas e as misturas destas com borracha virgem. As melhores condições foram obtidas com $20 \mathrm{~h}$ de incubação e concentração de bactéria 10/40(v/v). Com as misturas de borracha curada e biotratadas por microondas foram obtidos os melhores resultados (propriedades semelhantes a novas 
composições de pneus), se comparadas com aquelas biotratadas ou irradiadas com microondas, individualmente.

Ku et al., em $2002^{27}$, revisaram tecnologias de microondas, métodos de processamento e aplicações industriais. O objetivo do trabalho foi fornecer um guia para os interessados no uso de microondas, para melhorar o processamento de materiais atuais. Os fundamentos de microondas foram descritos, para dar um breve conhecimento das vantagens e limitações de microondas no processamento de materiais. Além disso, as limitações no entendimento atual foram incluídas como um guia para usuários potenciais, para pesquisa futura e atividades de desenvolvimento. Exemplos de aplicações de sucesso foram dados para ilustrar as características dos materiais, equipamentos e métodos de processamento aplicáveis a microondas industriais, tais como: sinterização de compostos de cerâmica/matriz cerâmica e processamento de pós, de compostos de polímeros/matriz de polímeros, de materiais de plasma e de minerais. Também foram feitas considerações econômicas e fornecidos custos, como guias na determinação da viabilidade do uso de microondas para processamento de materiais, mostrando que o capital gasto difere muito e dependem da potência, freqüência, tamanho, projeto do aplicador, fabricantes e mercado do equipamento.

Zhou et al., em $2003^{24}$, discutiram os princípios fundamentais do processamento de polímeros com microondas. Esta tecnologia foi pesquisada no processo de cura de resinas epóxi com diversas proporções de agente de cura. As propriedades mecânicas das amostras de polímeros curados foram medidas e analisadas, para verificar de que maneira as microondas podem melhorá-las. Os resultados também mostraram que as microondas podem diminuir o tempo de cura, temperatura e consumo de agente de cura.

Yoo et $\mathrm{al}^{39}$, em 2006, descreveram um equipamento para tratar continuamente a superfície de restos de EPDM em forma de pó, por meio de microondas. O sistema consistia de uma extrusora, na qual o funil de alimentação de carga $(5 \mathrm{~kg} / \mathrm{h}$ a $20 \mathrm{~kg} / \mathrm{h})$ recebia o pó de borracha. Na saída da extrusora, o material era transportado por uma esteira horizontal, dentro de uma câmara, na qual havia diversos geradores de microondas acoplados ( $3 \mathrm{~kW}$ de potência). A temperatura das amostras variou de $150^{\circ} \mathrm{C}$ a $250^{\circ} \mathrm{C}$, durante a passagem pela câmara, de no máximo 120s. Após esta etapa, as amostras eram resfriadas com ar, saindo da câmara com $50^{\circ} \mathrm{C}$ a $60^{\circ} \mathrm{C}$. A borracha resfriada passava por um funil 
de descarga do pó, acoplado a um recipiente final. Com esta metodologia, houve um aumento de aproximadamente $10 \%$ para resistência a tração e alongamento e o material reciclado apresentava uma superfície menos áspera e processável com propriedades físico-químicas melhoradas. 


\section{MATERIAIS E MÉTODOS}

\subsection{Amostras}

Para o estudo das interações das microondas com esse tipo de borracha, foram preparadas formulações de amostras de policloropreno (CR) resistentes a solventes e graxas, para uso na indústria automobilística, como gaxeta, coifa ou junta homocinêtica, entre outros. Nestas preparações, foram empregadas composições, usando como carga de reforço o Negro de Fumo (NF), e Bióxido de Silício $\left(\mathrm{SiO}_{2}\right)$, como apresentado nas TABS. 4 e 5.

A incorporação de cargas particuladas, como NF, aumenta o desempenho mecânico de elastômeros vulcanizados. O termo reforço, em tecnologia de polímeros, significa aumento da resistência ao rasgamento, à tração e à abrasão. Uma conseqüência prática do reforço é o aumento da vida útil do artefato final de borracha. As cargas também aumentam o módulo de elasticidade e são freqüentemente usadas para esse propósito, sendo que o NF atua mais eficazmente nestas propriedades do que o $\mathrm{SiO}_{2}{ }^{40}$.

A formulação usada foi baseada em normas aplicadas à indústria automobilística e o tipo de cloropreno empregado foi o Tipo W.

Tabela 4 - Formulação básica para preparação de amostra de CR com NF.

\begin{tabular}{l|r}
\hline \multicolumn{1}{c|}{ Ingredientes } & \multicolumn{1}{c}{ phr } \\
\hline Neoprene W & 100,0 \\
\hline Óxido de Magnésio & 4,0 \\
\hline Acido Esteárico & 0,8 \\
\hline Carbonato de Cálcio & 20,0 \\
\hline Negro de Fumo & 40,0 \\
\hline Cera Antiozonante & 3,0 \\
\hline Antioxidante & 2,0 \\
\hline Cera de Polietileno & 2,5 \\
\hline Óleo Aromático & 20,0 \\
\hline Oxido de Zinco & 5,0 \\
\hline MBTS & 0,4 \\
\hline NA 22 & 0,8 \\
\hline
\end{tabular}


Tabela 5 - Formulação básica para preparação de amostra de CR com $\mathrm{SiO}_{2}$.

\begin{tabular}{c|c}
\hline Ingredientes & phr \\
\hline Neoprene W & 100,0 \\
\hline Óxido de Magnésio & 4,0 \\
\hline Acido Esteárico & 0,8 \\
\hline Carbonato de Cálcio & 20,0 \\
\hline Bióxido de Silício & 25 \\
\hline Cera Antiozonante & 3,0 \\
\hline Antioxidante & 2,0 \\
\hline Cera de Polietileno & 2,5 \\
\hline Óleo Aromático & 20,0 \\
\hline Oxido de Zinco & 5,0 \\
\hline MBTS & 0,4 \\
\hline NA 22 & 0,8
\end{tabular}

As amostras foram preparadas em um misturador de cilindro aberto (Copê), com dois rolos (FIG.4), capacidade para 40kg, segundo norma ASTM D$3182^{41}$, em temperatura de $50^{\circ} \mathrm{C}$ a $60^{\circ} \mathrm{C}$. O tipo de Negro de Fumo usado foi o Statex FEF 550 e o de Bióxido de Silício, Zeosil 175.

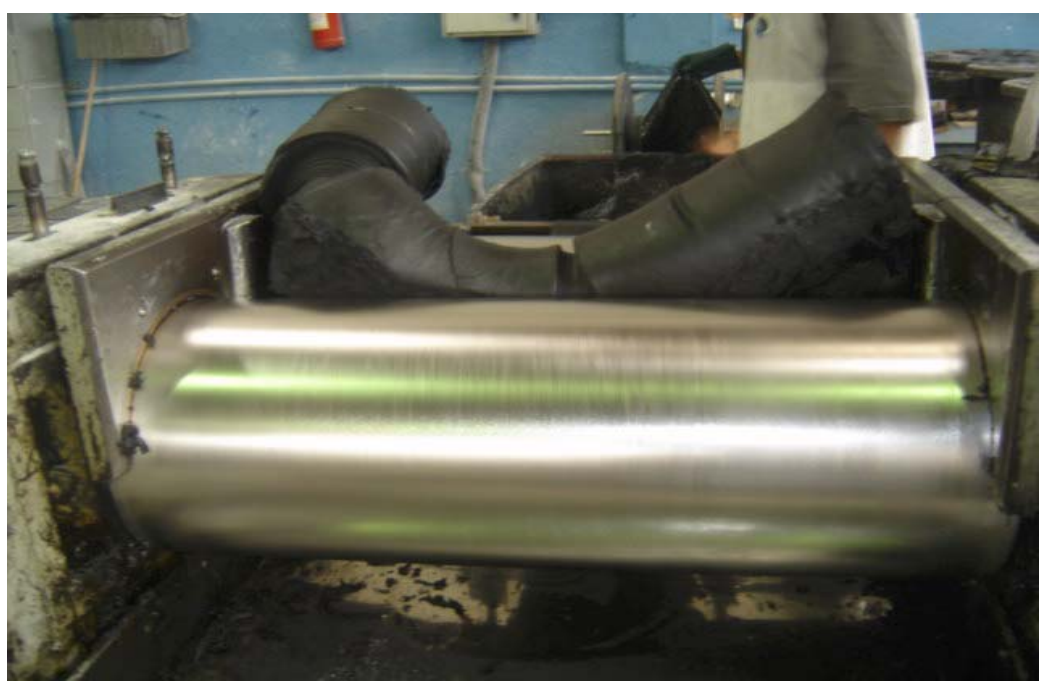

FIGURA 4 - Misturador de cilindro aberto de dois rolos (Copê). 
As mantas de cloropreno obtidas foram cortadas em pedaços de aproximadamente $1 \mathrm{~cm} \times 1 \mathrm{~cm}$, com massa total de $250 \mathrm{~g}$, para ser irradiada, conforme pode ser visto na FIG.5.

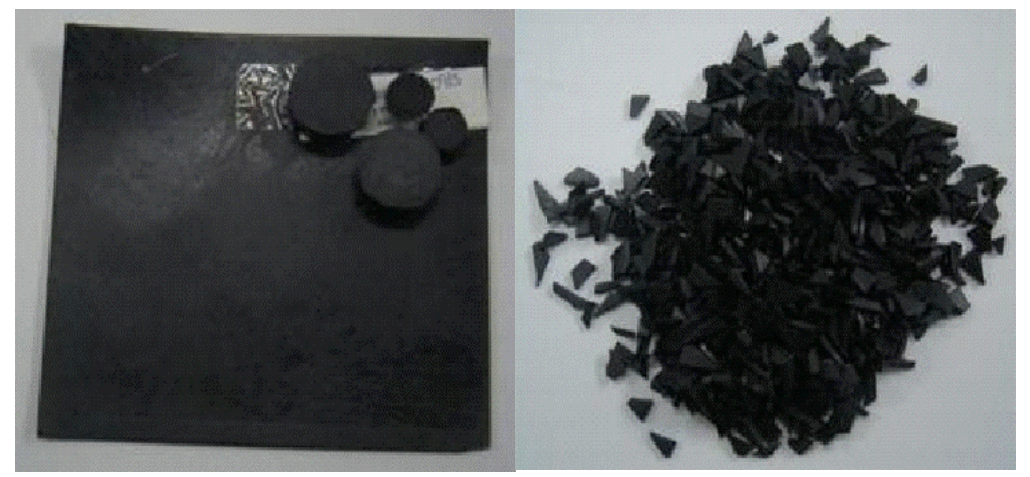

FIGURA 5 - Modelo de manta de cloropreno antes e após serem cortadas.

\subsection{Irradiações}

As amostras citadas anteriormente foram irradiadas na unidade de geração de energia de microondas, projetada, fabricada e montada no IPEN ${ }^{42}$, como mostrado na FIG. 6. Este equipamento opera com freqüência de $2.450 \mathrm{MHz}$ e potências de $1.000 \mathrm{~W}$ a 3.000W. Possui, ainda, um sistema de saída de gases residuais e de coleta do material, além de controle automático do tempo de irradiação. As temperaturas das amostras foram monitoradas por um termopar acoplado a um medidor.

As irradiações foram realizadas variando-se o tempo e a potência, de acordo com a TAB.6, para compostos com Negro de Fumo e TAB.7, para compostos com Bióxido de Silício.

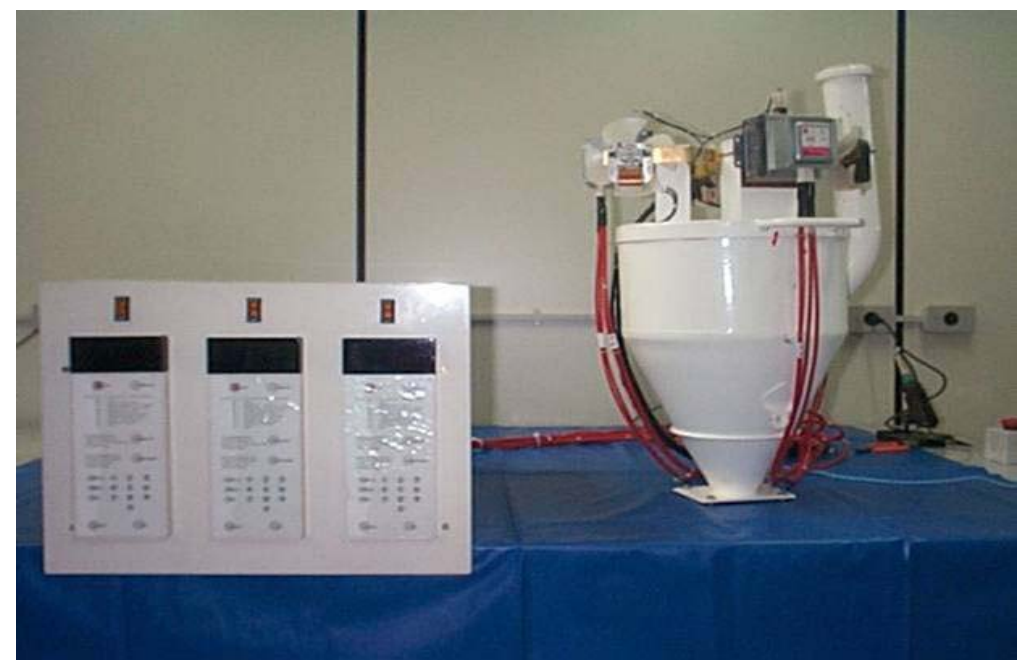

FIGURA 6 - Unidade removível de geração de energia - Microondas (IPEN). 
TABELA 6 - Dados das irradiações de amostras de CR com Negro de Fumo.

\begin{tabular}{c|c|c}
\hline Amostra & Tempo (s) & Potência (W) \\
\hline A1 & 43 & 1000 \\
\hline A2 & 60 & 1000 \\
\hline A3 & 120 & 1000 \\
\hline A4 & 150 & 1000 \\
\hline A5 & 180 & 1000 \\
\hline A6 & 210 & 1000 \\
\hline A7 & 240 & 1000 \\
\hline A8 & 300 & 1000 \\
\hline A9 & 360 & 1000 \\
\hline A10 & 60 & 2000 \\
\hline A11 & 90 & 2000 \\
\hline A12 & 120 & 2000 \\
\hline A13 & 30 & 3000 \\
\hline
\end{tabular}

TABELA 7 - Dados das irradiações de amostras de CR com Bióxido de Silício.

\begin{tabular}{c|c|c}
\hline Amostra & Tempo (s) & Potência (W) \\
\hline B1 & 90 & 1000 \\
\hline B2 & 120 & 1000 \\
\hline B3 & 150 & 1000 \\
\hline B4 & 180 & 1000 \\
\hline B5 & 210 & 1000 \\
\hline B6 & 240 & 1000 \\
\hline B7 & 60 & 2000 \\
\hline B8 & 90 & 2000 \\
\hline B9 & 120 & 2000 \\
\hline B10 & 130 & 2000 \\
\hline B11 & 150 & 2000 \\
\hline B12 & 210 & 2000 \\
\hline B13 & 120 & 3000 \\
\hline
\end{tabular}

\subsection{Processamento e Caracterizações}

Para caracterização das amostras, antes e após as irradiações, foram realizados ensaios de cada composição em triplicata, e os resultados obtidos foram à média aritmética dos valores parciais. As analise foram feitas de acordo com as normas ASTM. Os corpos-de-prova (FIG. 7) para realizar as análises foram preparados conforme norma ASTM D-3182 ${ }^{41}$, em prensa Luxor, com 
dimensões de mesa $300 / 350 \mathrm{~mm}$. Todas as amostras foram vulcanizadas em temperatura de $160^{\circ} \mathrm{C}$, durante $15 \mathrm{~min}$. Para controle do processo, foram verificadas as propriedades dadas a seguir.

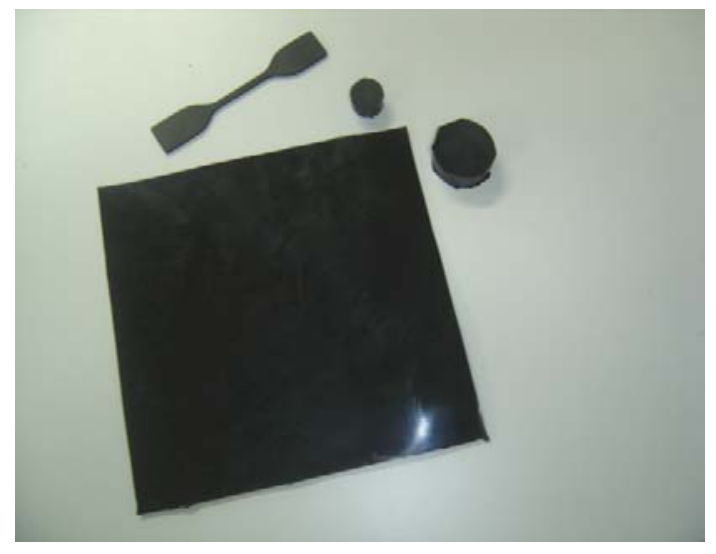

FIGURA 7 - Corpos-de-prova para análises.

\subsubsection{Densidade}

A densidade é uma característica importante, pois dá uma idéia da composição do material elastômerico. A unidade usual empregada é $\circ \mathrm{g} / \mathrm{cm}^{3}$. A densidade das amostras foi medida por meio de balança analítica AM 220 (Marte), conforme é mostrado na FIG.8, com dispositivo específico. A norma ASTM D$297^{43}$ foi empregada nas medidas.

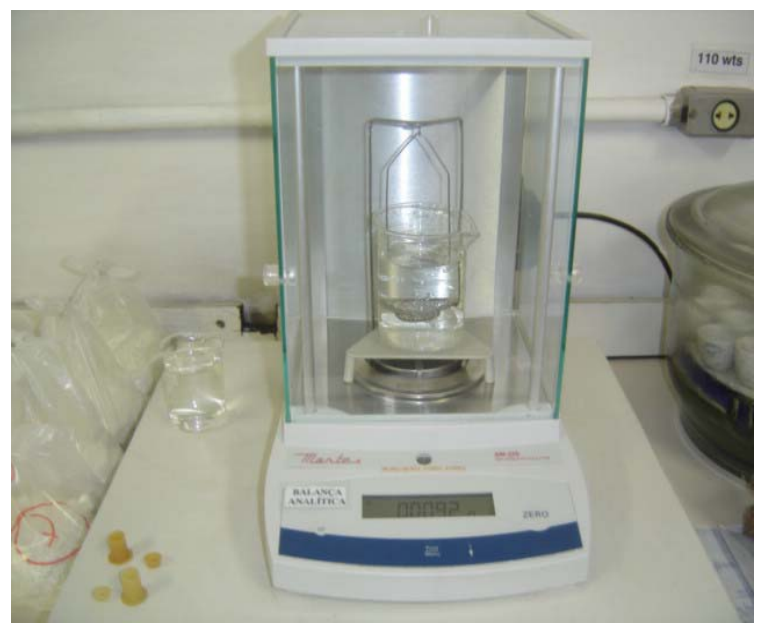

FIGURA 8 - Balança analítica AM 220 (Marte), com dispositivo específico. 


\subsubsection{Dureza}

A dureza é uma das propriedades mais medidas da borracha e o durômetro é o instrumento de prova utilizado. Esta grandeza física é a medida da resistência imposta à penetração de uma superfície, por um instrumento de dimensões e carga determinadas. $\mathrm{O}$ aparelho empregado foi um durômetro Shore A, Bareiss (FIG.9), que possui uma agulha de formato tronco cônico, sobressaindo da caixa do aparelho, mantida na posição zero da escala por ação de uma mola. Ao ser comprimida contra o corpo-de-prova, a agulha tende a entrar na caixa, comprimindo a mola. Este movimento é transmitido ao ponteiro da escala. A calibração é arbitrária, desde o zero (mole) até 100 (dura). As análises foram realizadas de acordo com a norma ASTM D-2240 44 .

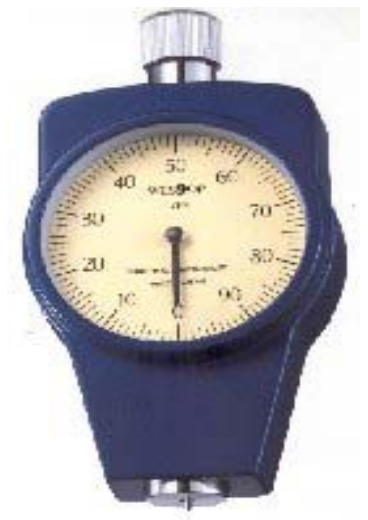

Figura 9 - Durômetro Shore A para borrachas.

\subsubsection{Resistência a Tração e Alongamento}

Nestes ensaios, são medidos os seguintes parâmetros: módulo elástico, tensão de ruptura e alongamento na ruptura. O módulo (MPa; psi; $\mathrm{kgf} / \mathrm{cm}^{2}$ ) é a força por unidade de área da secção transversal original do corpo-deprova, necessária para distendê-lo a determinado alongamento. A tensão de ruptura (MPa; psi; $\mathrm{kgf} / \mathrm{cm}^{2}$ ) é a força por unidade de área da secção original do corpo-de-prova, necessária para rompê-lo. Utilizam-se corpos-de-prova na forma de halteres, de $10 \mathrm{~cm}$ a $13 \mathrm{~cm}$ de extensão, recortados de mantas de borracha e marcados na parte mais estreita com dois traços de referência. Ambas extremidades são presas às garras da máquina de ensaio. A garra inferior, 
acionada mecanicamente, é afastada e o corpo-de-prova é esticado até a ruptura. Portanto, o alongamento na ruptura é produzido pela aplicação de uma força entre dois traços (distância de 25,4mm) marcados no corpo-de-prova. É expresso em porcentagem da distância inicial entre os centros destes traços e foi medido manualmente com auxílio de uma régua. Estes ensaios foram realizados em um Dinamômetro ZR60/300 (Otto Wolpert-Werke) (FIG. 10), pela norma ASTM D$412^{45}$.

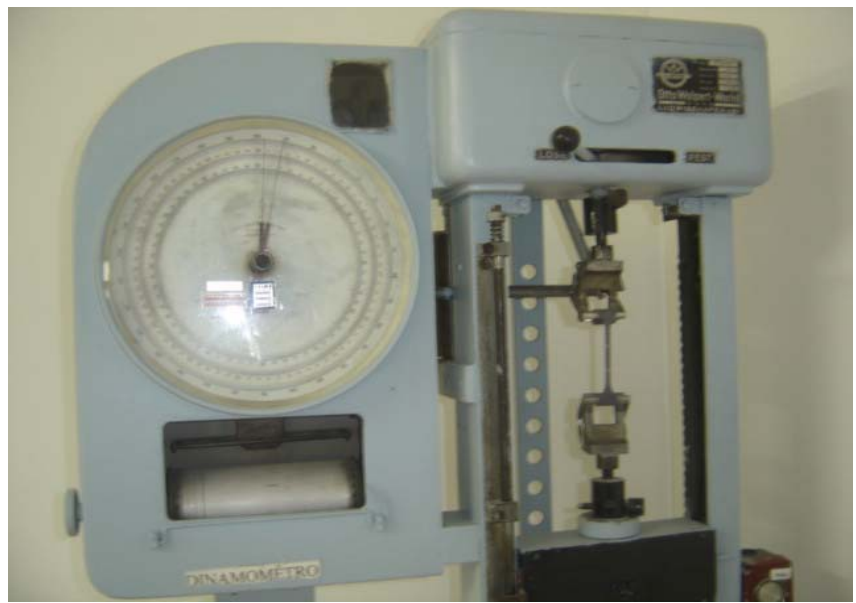

FIGURA 10 - Dinamômetro ZR60/300 (Otto Wolpert-Werke).

\subsubsection{Resistência ao Envelhecimento}

O envelhecimento natural é bastante lento e pode ser acelerado por meio de métodos de ensaio de diferentes fatores de degradação: intempérie, calor, luz, ozônio, ar, oxigênio, entre outros. Para este teste foi utilizado o ensaio para calor, em estufa com ar circulante, modelo 315 SE (FANEM), FIG. 11, em $100^{\circ} \mathrm{C}$ por $70 \mathrm{~h}$, conforme norma ASTM D- $573^{46}$.

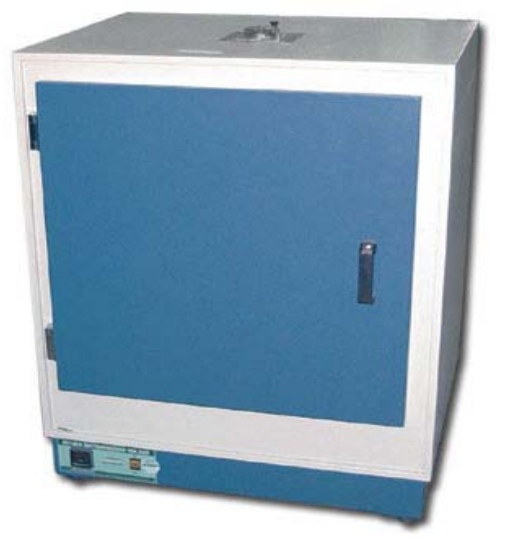

FIGURA 11 - Estufa com ar circulante. 


\subsubsection{Deformação Permanente por Compressão (DPC)}

Existem dois métodos para determinação da compressão permanente: método A (carga constante) e método B (deflexão constante). São medidas as porcentagens do retorno da espessura de um material elastomérico, após ser submetido à determinada compressão, durante um período de tempo estabelecido. A compressão é padronizada em aproximadamente $25 \%$ e obtida através do uso de espaçadores de aço (FIG.12). Os ensaios foram realizados conforme norma ASTM D-395 ${ }^{47}$, método $\mathrm{B}$, com temperatura de $100^{\circ} \mathrm{C}$, durante 22h, em estufa de ar circulante, modelo 315 SE (FANEM).

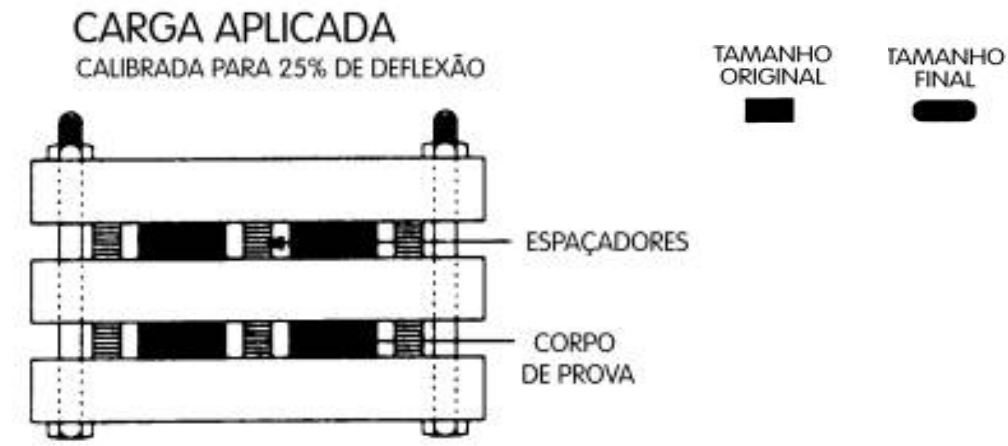

FIGURA 12 - Aparelho para ensaio de DPC.

\subsubsection{Teor de Cinzas}

No teste de cinzas, é analisada a quantidade aproximada do conteúdo de carga mineral presente na amostra. Os ensaios foram realizados em um forno mufla (Quimis) (FIG. 13), com $600^{\circ} \mathrm{C}$ de temperatura, durante $4 \mathrm{~h}$, segundo norma ASTM D-297 ${ }^{43}$.

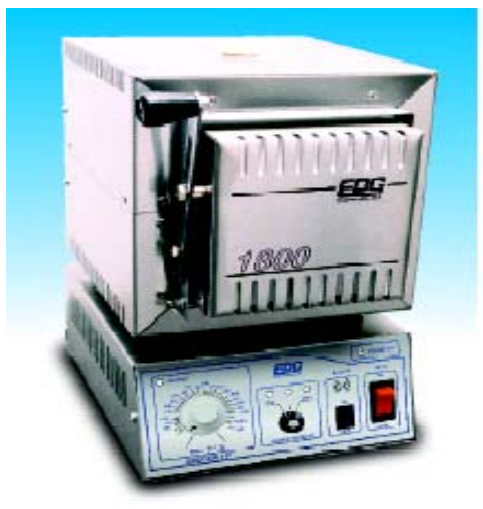

FIGURA 13 - Forno Mufla. 


\subsubsection{Reometria}

Por meio desta técnica, determinam-se as características de vulcanização em compostos de borracha, para o controle de qualidade no processo de produção deste tipo de artefato. Neste ensaio, a amostra utilizada é cisalhada entre duas placas ou pratos circulares (uma fixa - a inferior, que é aquecida na temperatura que se deseja realizar o teste; uma móvel - a superior) separadas por uma determinada distância. A determinação dos parâmetros reométricos foi feita em reômetro de disco oscilatório, modelo $100 \mathrm{~S}$ (Monsanto), (FIG.14), de acordo com a norma ASTM D-2084 ${ }^{48}$. Os parâmetros de vulcanização avaliados foram: $T_{\mathrm{S} 1}$ - tempo no qual a amostra apresenta menor rigidez (menor ponto da curva); $\mathrm{T}_{\mathrm{S2}}$ - tempo no qual a amostra começa a vulcanizar; $T_{90}-90 \%$ do tempo de vulcanização. As condições utilizadas nos ensaios foram: temperatura $-160^{\circ} \mathrm{C}$; arco de oscilação $-3^{\circ}$ e tempo -12 min. As curvas de vulcanização são obtidas pelo Torque (Ibf.in) em função do Tempo (min).

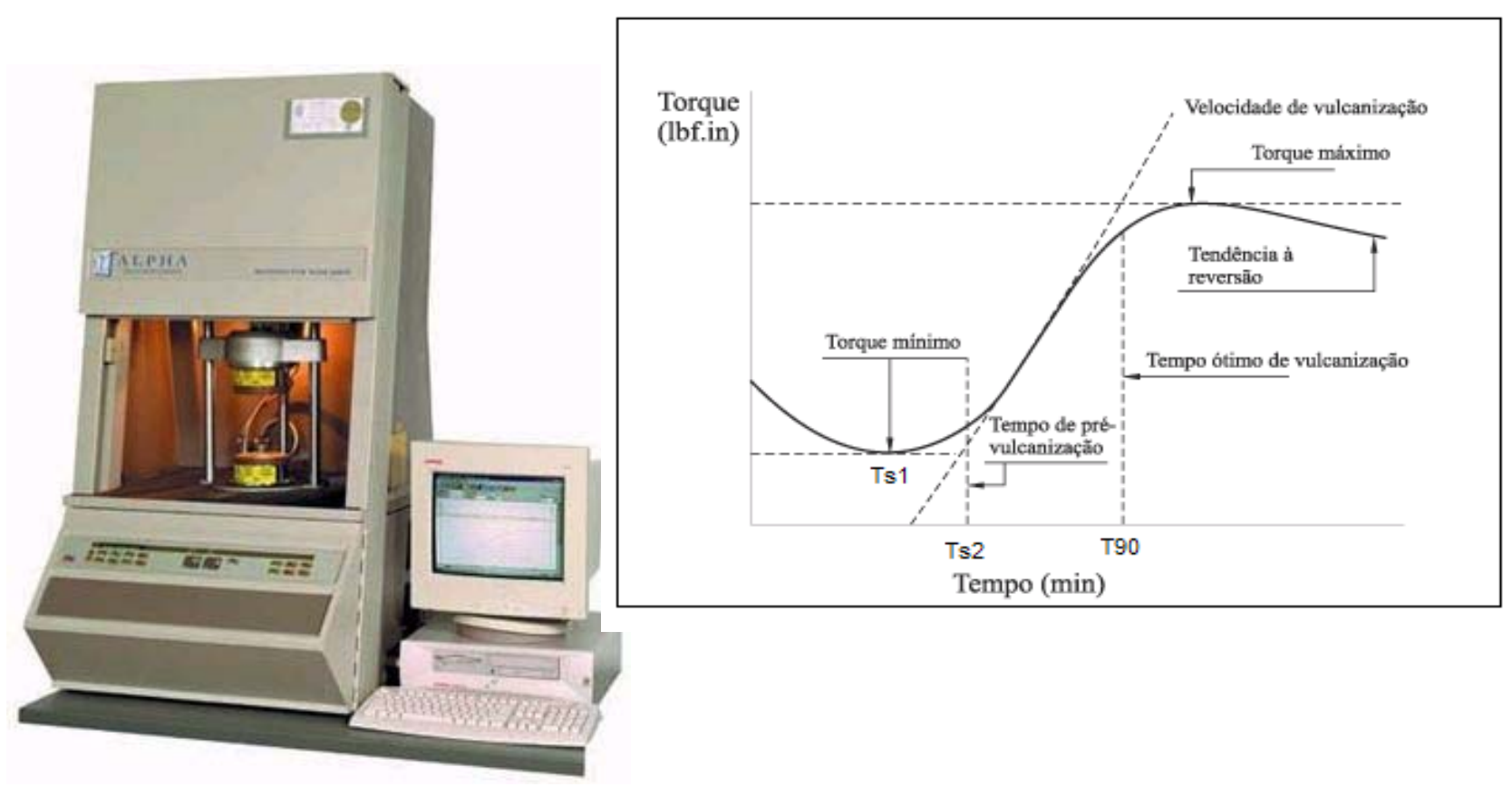

FIGURA 14 -Reômetro e Curva de reômetro (torque x tempo) 


\subsubsection{Determinação de gel, índice de inchamento (swelling) e índice de fluidez (DSV)}

Por meio destes testes, são determinadas as características de gel e o índice de inchamento dos polímeros vulcanizados. A porção de gel é usada para determinar a quantidade de borracha dissolvida em um solvente e é obtida pela evaporação deste. O índice de inchamento é determinado, comparando-se a massa inicial da amostra com a massa final, as variações indicam mudanças no sistema de polimerização. Nas borrachas ocorre o fenômeno de inchamento o qual é inversamente proporcional à densidade de ligações cruzadas ${ }^{49}$.

Os ensaios de inchamento (swelling), foram realizados nas amostras, utilizando-se tolueno (Merck) como solvente. Para estas análises, foi utilizada a norma ASTM D-3616 ${ }^{50}$. As amostras foram pesadas na mesma balança para medida de densidade (citada no item 4.3.1), com precisão de até $10^{-4} \mathrm{mg}$ (Marte) e imersas no solvente (FIG. 15), por um período de 16h, em seguida foram completamente limpos e repesados.

O grau de inchamento foi calculado de acordo com a equação:

$$
\mathrm{Q}=\left(m-m_{\circ}\right) / m_{0}
$$

Onde: $m_{0}$ é a massa inicial da amostra $(g)$ e $m$ é a massa final da amostra $(g)^{51}$.

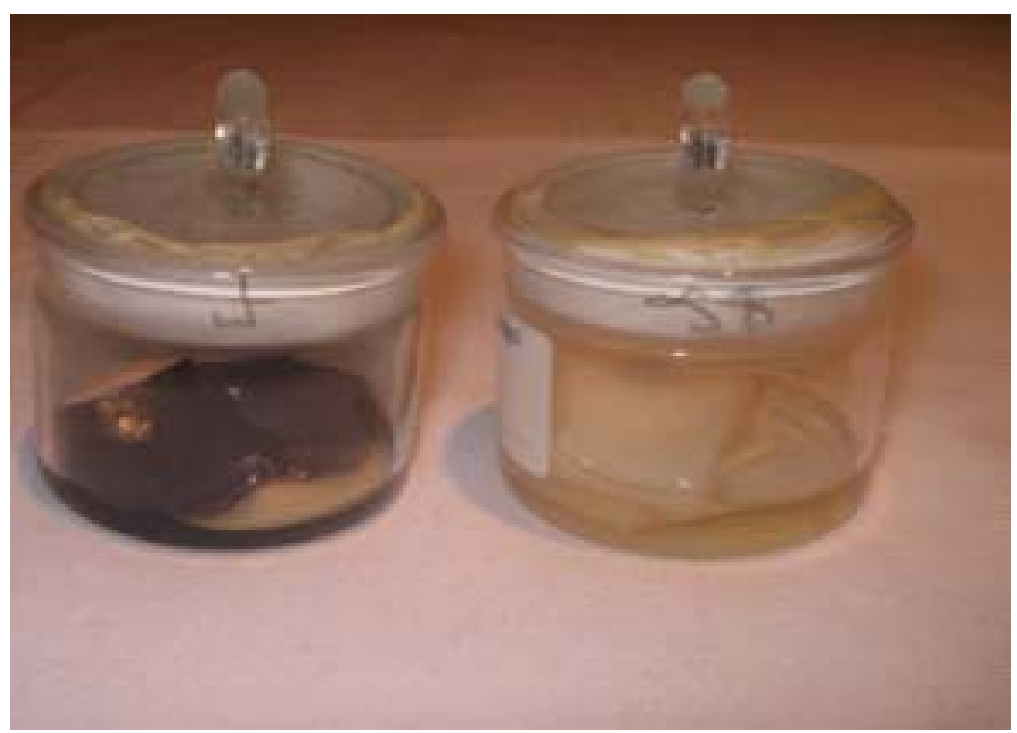

Figura 15 - Amostras de cloropreno imersas em tolueno. 


\section{RESULTADOS E DISCUSSÕES}

Todas as amostras irradiadas foram processadas novamente no cilindro de rolos, para confecção de mantas e respectivos corpos-de-prova. Em algumas delas, não foi possível confeccioná-los, pois apresentavam aspecto granular muito irregular, com odor característico de borracha queimada (degradada), como mostrado na FIG. 16. Em outras, foi possível confeccionar os corpos-de-prova, porém o material moldado não possuía aspecto compacto e ficou muito fragmentado. Portanto, não foram realizadas as caracterizações destas amostras.

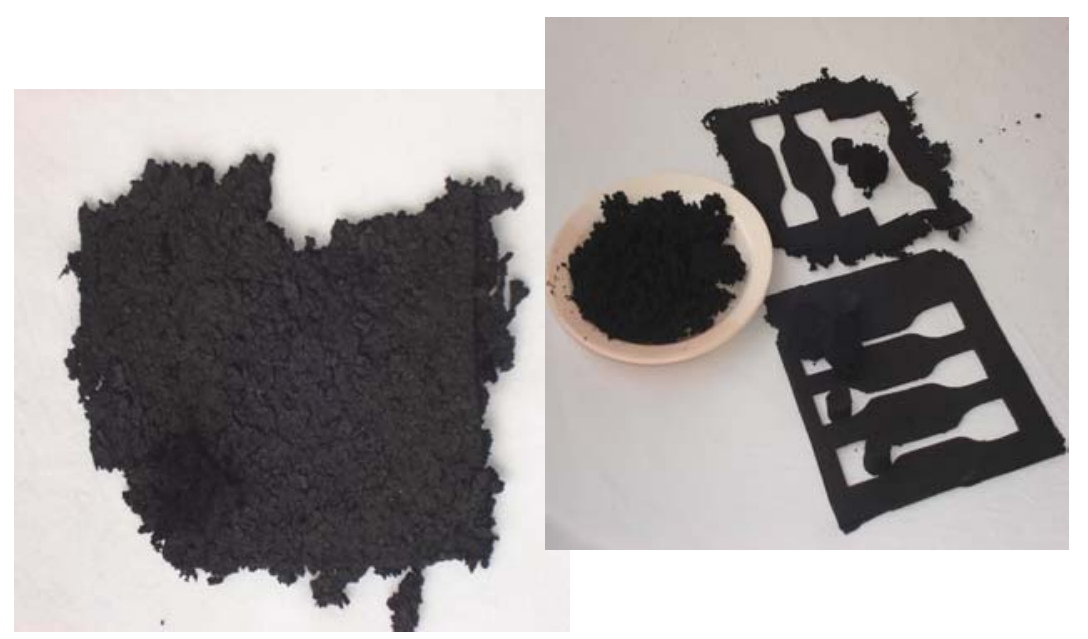

FIGURA 16 - Massa com aspecto granular muito irregular e corpos-de-prova fragmentados.

Neste trabalho, as especificações técnicas para massa original (A0), do composto formulado com NF, são mostradas na TAB. 8. Os resultados obtidos nas caracterizações das amostras de CR, antes e após irradiações, para formulações com NF são mostrados na TAB. 9.

TABELA 8 - Especificação do composto de CR com NF (A0).

\begin{tabular}{c|c}
\hline Propriedade & Especificação \\
\hline Dureza & $60 \pm 5$ shore A \\
\hline Densidade & $1,40 \pm 0,04 \mathrm{~g} / \mathrm{cm}^{3}$ \\
\hline Resistência Tração & 1000 psi mín. \\
\hline Alongamento & $350 \%$ mín \\
\hline Cinzas & $13,5 \pm 3,0 \%$ \\
\hline DPC & $40 \%$ máx \\
\hline
\end{tabular}


TABELA 9 - Amostras de CR (com NF) caracterizadas, antes e após irradiações.

\begin{tabular}{c|c|c|c|c|c|c|c}
\hline Amostra & $\begin{array}{c}\text { Dureza } \\
\text { (shore A) }\end{array}$ & $\begin{array}{c}\text { Densidade } \\
\left(\mathbf{g} / \mathbf{c m}^{\mathbf{3}}\right)\end{array}$ & $\begin{array}{c}\text { Tração } \\
\text { (psi) }\end{array}$ & $\begin{array}{c}\text { Alongamento } \\
\mathbf{( \% )}\end{array}$ & $\begin{array}{c}\text { Cinzas } \\
(\mathbf{\%})\end{array}$ & $\begin{array}{c}\text { DPC } \\
\mathbf{( \% )}\end{array}$ & $\begin{array}{c}\text { Swelling } \\
(\mathbf{Q})\end{array}$ \\
\hline A0 & 57 & 1,40 & 1428 & 500 & 14,09 & 20,46 & 1,25 \\
\hline A1 & 48 & 1,35 & 891 & 780 & 12,20 & 18,43 & - \\
\hline A2 & 58 & 1,38 & 572 & 300 & 22,65 & 14,18 & 3,11 \\
\hline A3 & 48 & 1,37 & 690 & 700 & 13,10 & 14,90 & 1,35 \\
\hline A4 & 45 & 1,38 & 688 & 700 & 12,50 & 15,70 & 1,19 \\
\hline A5 & 50 & 1,25 & 700 & 100 & 15,52 & 12,40 & 1,53 \\
\hline A6 & 49 & 1,19 & 95 & 140 & - & - & 1,36 \\
\hline A7 & 47 & 1,25 & 102 & 140 & - & - & 1,45 \\
\hline A8 & 45 & 1,17 & 82 & 120 & - & - & 1,57 \\
\hline A9 & 52 & 1,23 & 97 & 100 & - & - & 1,43 \\
\hline A10 & - & - & 1825 & 450 & 14,28 & - & - \\
\hline A11 & - & - & - & - & - & - & - \\
\hline A12 & - & - & - & - & - & - & - \\
\hline A13 & - & - & 1890 & 460 & 14,22 & - & - \\
\hline
\end{tabular}

Todas as amostras obtidas tiveram suas propriedades alteradas em função das irradiações, conforme, pode ser observado na FIG. 17, para os parâmetros de vulcanização: $T_{S 1}, T_{S 2}$ e $T_{90}$. Na FIG. 18, são apresentados os resultados de dureza, onde se pode observar que na maioria das amostras o tempo de exposição influiu nos valores de dureza encontrados, o que caracteriza perdas nas propriedades físicas e um material mais mole.

Na FIG 19 são mostrados os resultados para o teste de resistência a tração e alongamento, pela qual verifica-se uma perda de propriedades à medida que o tempo de exposição é aumentado. Quando foram aplicadas potências maiores que $1.000 \mathrm{~W}$, nas irradiações, nota-se uma elevação acentuada no valor de resistência a tração, porém baixos valores de alongamento, que podem significar que os compostos foram deteriorados (perda de elasticidade). Nestas figuras, podem ser observados os efeitos das irradiações nas massas obtidas. 


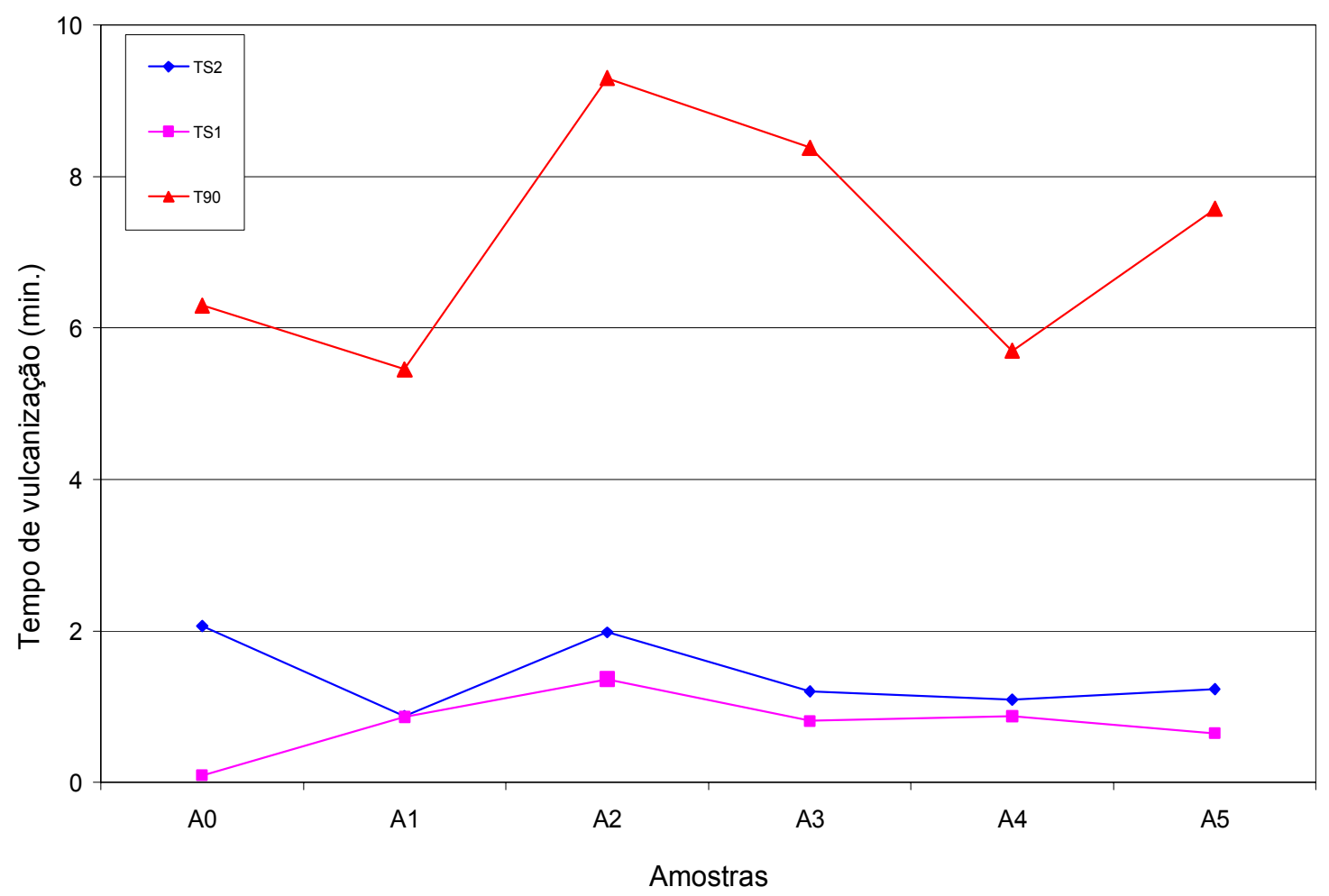

FIGURA 17 - Parâmetros de vulcanização da composição de CR com NF.

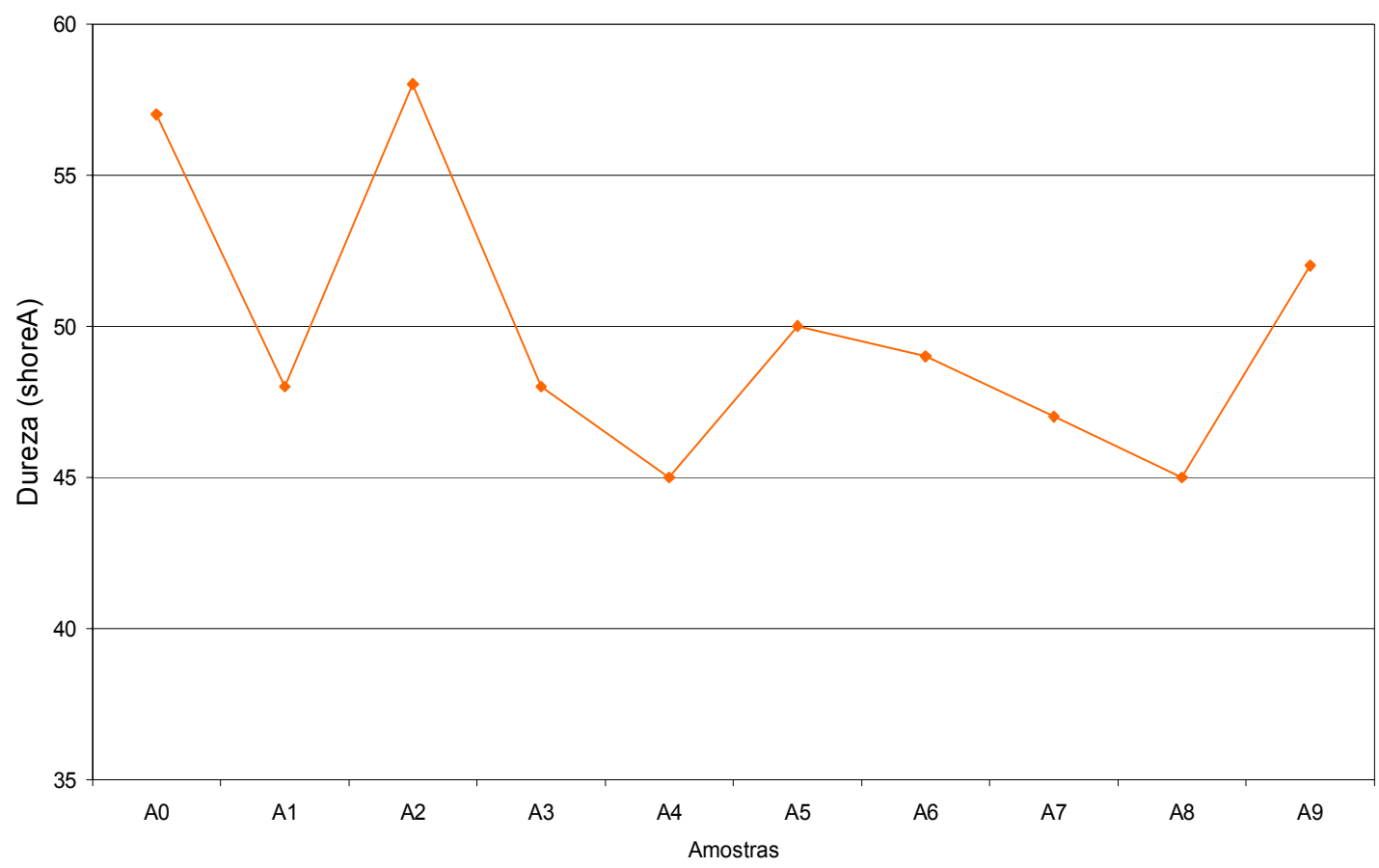

FIGURA 18 - Variação de dureza da composição de CR com NF. 


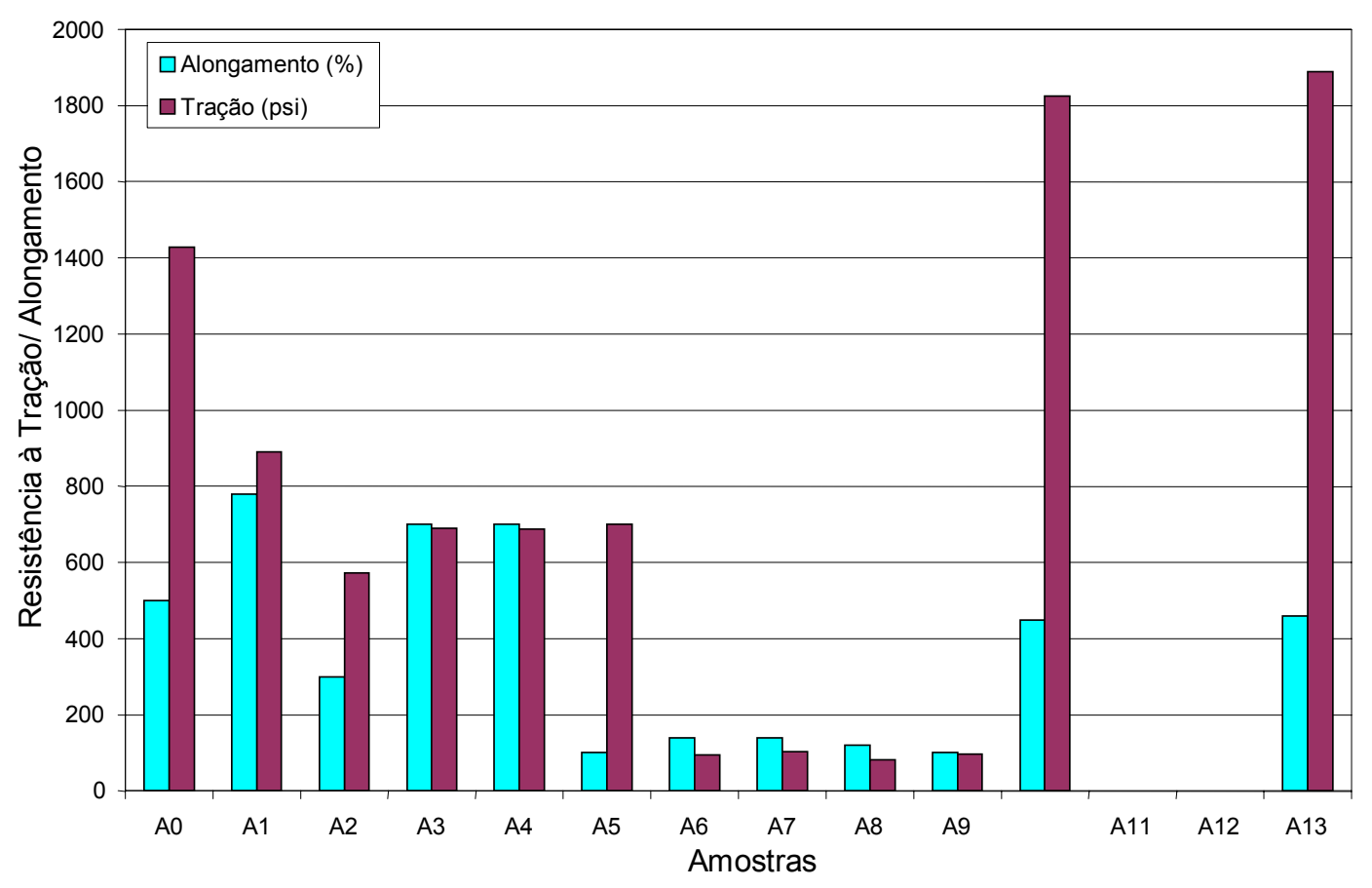

FIGURA 19 - Variação de Tração/Alongamento da composição de CR com NF.

A amostra A2 foi a que apresentou resultados mais satisfatórios, pois além do valor de tgo $_{90}$ ser maior que o da massa original - A0 (necessitou de um tempo maior de vulcanização, caracterizando perda de aceleração), notou-se que os valores de resistência a tração e alongamento estavam mais baixos. Esta amostra não aparentava aspecto deteriorado e o índice de inchamento (swelling) obtido, comparado com todas as outras analisadas, mostrou valor mais satisfatório (visualmente mais inchada que as demais - FIG.20). Após a imersão no solvente, algumas amostras se dissolviam e outras ficam quebradiças. Isto pode ser justificado em virtude das ligações cruzadas dos polímeros, que quando imersos em solventes específicos, indicam a intensidade destas ligações, consideradas inversamente proporcionais ao grau de inchamento da borracha ${ }^{51}$. Na FIG. 21, pode ser vista a variação dos índices de inchamento, para algumas amostras. 


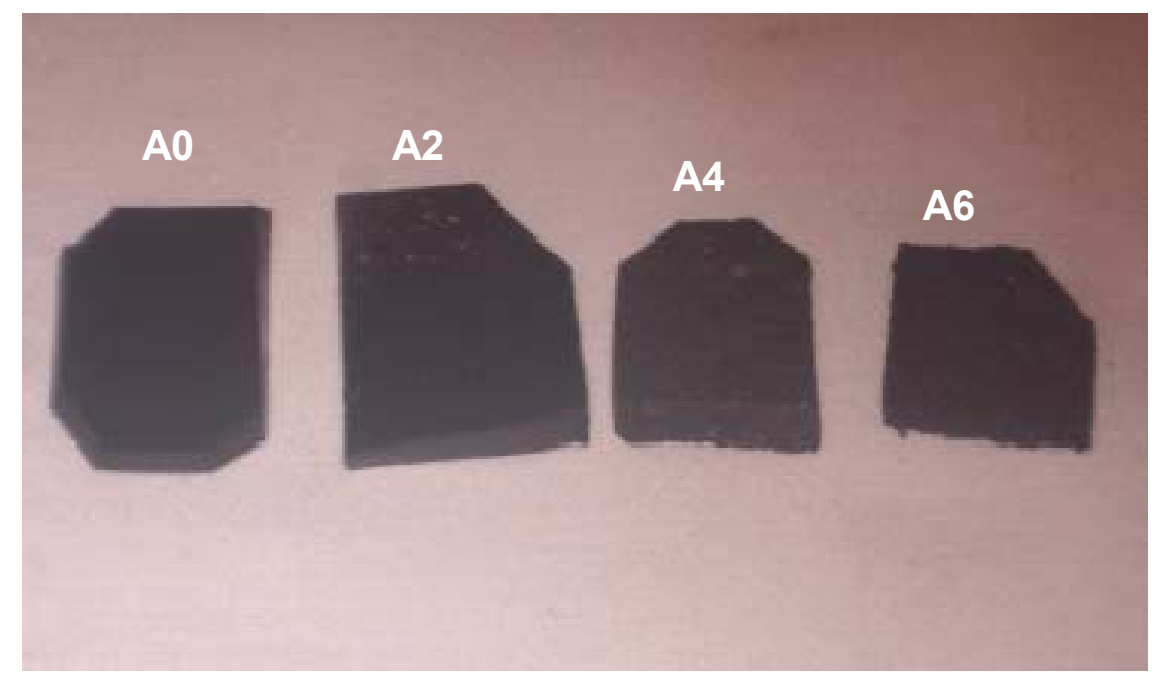

FIGURA 20 - Amostras da composição de CR com NF após imersão no solvente.

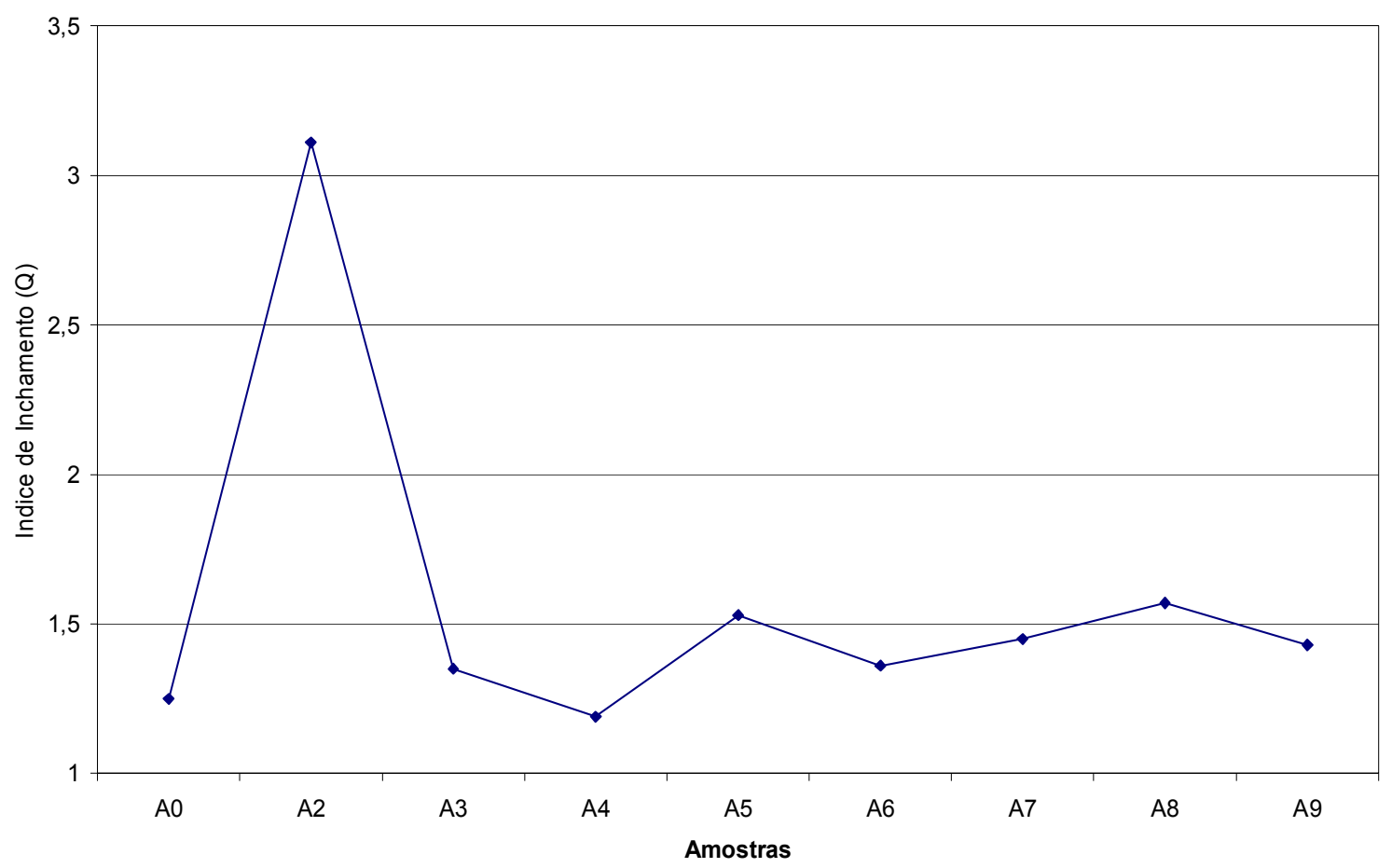

FIGURA 21 - Variação dos índices de inchamento da composição de CR com NF. 
Foram realizados os mesmos tipos de caracterizações, antes e após as irradiações para amostras de $\mathrm{CR}$, formuladas com Bióxido de Silício. As especificações da amostra original (B0) são mostradas na TAB. 10 e os resultados das análises podem ser vistos na TAB.11.

TABELA 10 - Especificação do composto de $\mathrm{CR}$ com $\mathrm{SiO}_{2}$.

\begin{tabular}{c|c}
\hline Propriedade & Especificação \\
\hline Dureza & $50 \pm 5$ shore $A$ \\
\hline Densidade & $1,40 \pm 0,04 \mathrm{~g} / \mathrm{cm}^{3}$ \\
\hline Resistência Tração & $800 \mathrm{psi}$ mín. \\
\hline Alongamento & $700 \%$ mín \\
\hline Cinzas & $22,5 \pm 3,0 \%$ \\
\hline DPC & $40 \%$ máx \\
\hline
\end{tabular}

TABELA 11 - Amostras de $\mathrm{CR}\left(\mathrm{com} \mathrm{SiO}_{2}\right)$ caracterizadas, antes e após Irradiações.

\begin{tabular}{c|c|c|c|c|c|c|c}
\hline Amostra & $\begin{array}{c}\text { Dureza } \\
(\mathbf{s h o r e ~ A ) ~}\end{array}$ & $\begin{array}{c}\text { Densidade } \\
\left(\mathbf{g} / \mathbf{c m}^{\mathbf{3}} \mathbf{)}\right.\end{array}$ & $\begin{array}{c}\text { Tração } \\
\text { (psi) }\end{array}$ & $\begin{array}{c}\text { Alongamento } \\
\mathbf{( \% )}\end{array}$ & $\begin{array}{c}\text { Cinzas } \\
(\mathbf{\%})\end{array}$ & $\begin{array}{c}\text { DPC } \\
(\mathbf{\%})\end{array}$ & $\begin{array}{c}\text { Swelling } \\
(\mathbf{Q})\end{array}$ \\
\hline B0 & 50 & 1,40 & 934 & 1000 & 22,88 & 26,54 & 4,23 \\
\hline B1 & 47 & 1,33 & 496 & 420 & 19,98 & 3,41 & 1,83 \\
\hline B2 & 42 & 1,39 & 949 & 1000 & 23,39 & 2,79 & 2,60 \\
\hline B3 & 48 & 1,32 & 591 & 420 & 18,57 & 22,80 & 2,68 \\
\hline B4 & 54 & 1,40 & 977 & 800 & 23,82 & 5,28 & 1,82 \\
\hline B5 & 46 & 1,31 & 337 & 320 & 18,40 & 25,09 & 1,82 \\
\hline B6 & 46 & 1,39 & 985 & 660 & 24,11 & 4,47 & 2,57 \\
\hline B7 & 41 & 1,40 & 1105 & 1000 & 23,56 & 17,34 & 2,57 \\
\hline B8 & 52 & 1,32 & 491 & 400 & 20,44 & 2,67 & 1,90 \\
\hline B9 & 40 & 1,39 & 1255 & 1000 & 22,87 & 5,45 & 2,75 \\
\hline B10 & 53 & 1,37 & 691 & 700 & 27,56 & 52,25 & 1,87 \\
\hline B11 & 46 & 1,34 & 394 & 420 & 18,37 & 2,70 & 1,88 \\
\hline B12 & 53 & 1,33 & 1223 & 320 & 18,58 & 4,70 & 1,44 \\
\hline B13 & 42 & 1,39 & 804 & 700 & 22,92 & 13,28 & 2,54 \\
\hline
\end{tabular}

Podem ser observados, ainda, na FIG.22, os mesmos parâmetros de vulcanização utilizados nas formulações de massas com Negro de Fumo, ou seja, $T_{S 1}, T_{S 2}$ e $T_{90}$. 


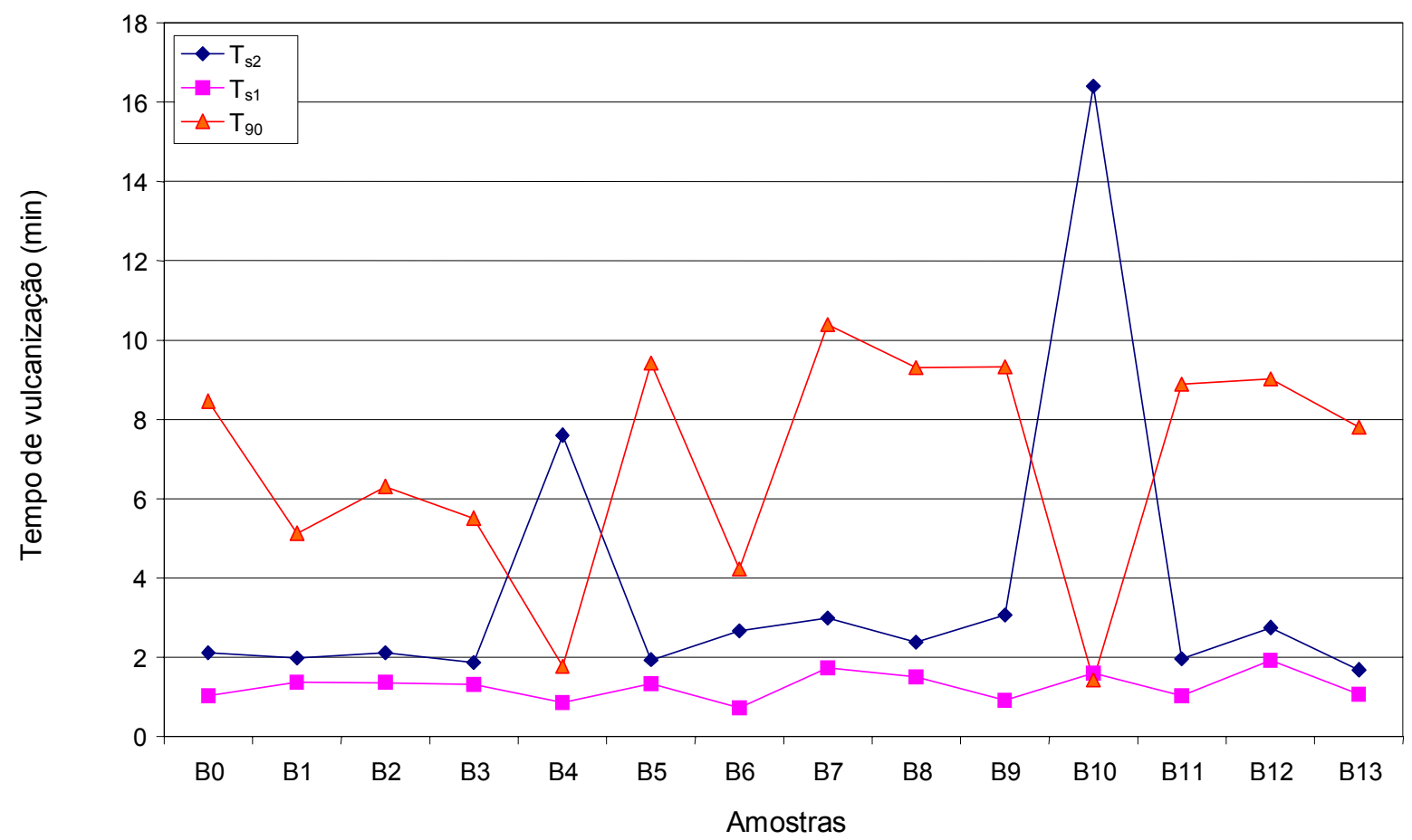

FIGURA 22 - Parâmetros de vulcanização da composição de CR com $\mathrm{SiO}_{2}$.

Os resultados obtidos no teste de dureza são mostrados na FIG. 23 e na FIG. 24, os parâmetros de tração e alongamento.

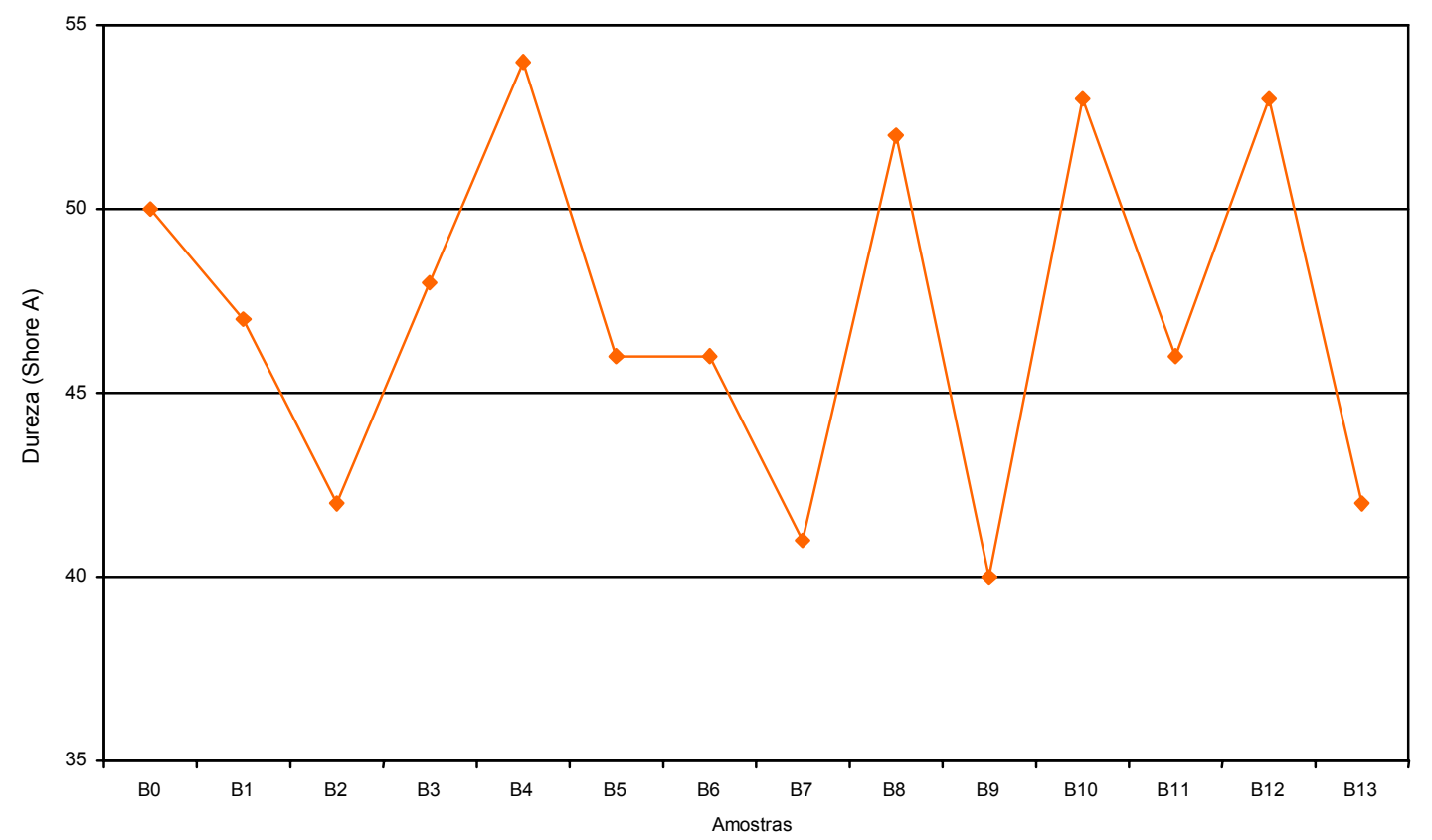

Figura 23 - Variação de dureza da composição de CR com $\mathrm{SiO}_{2}$. 


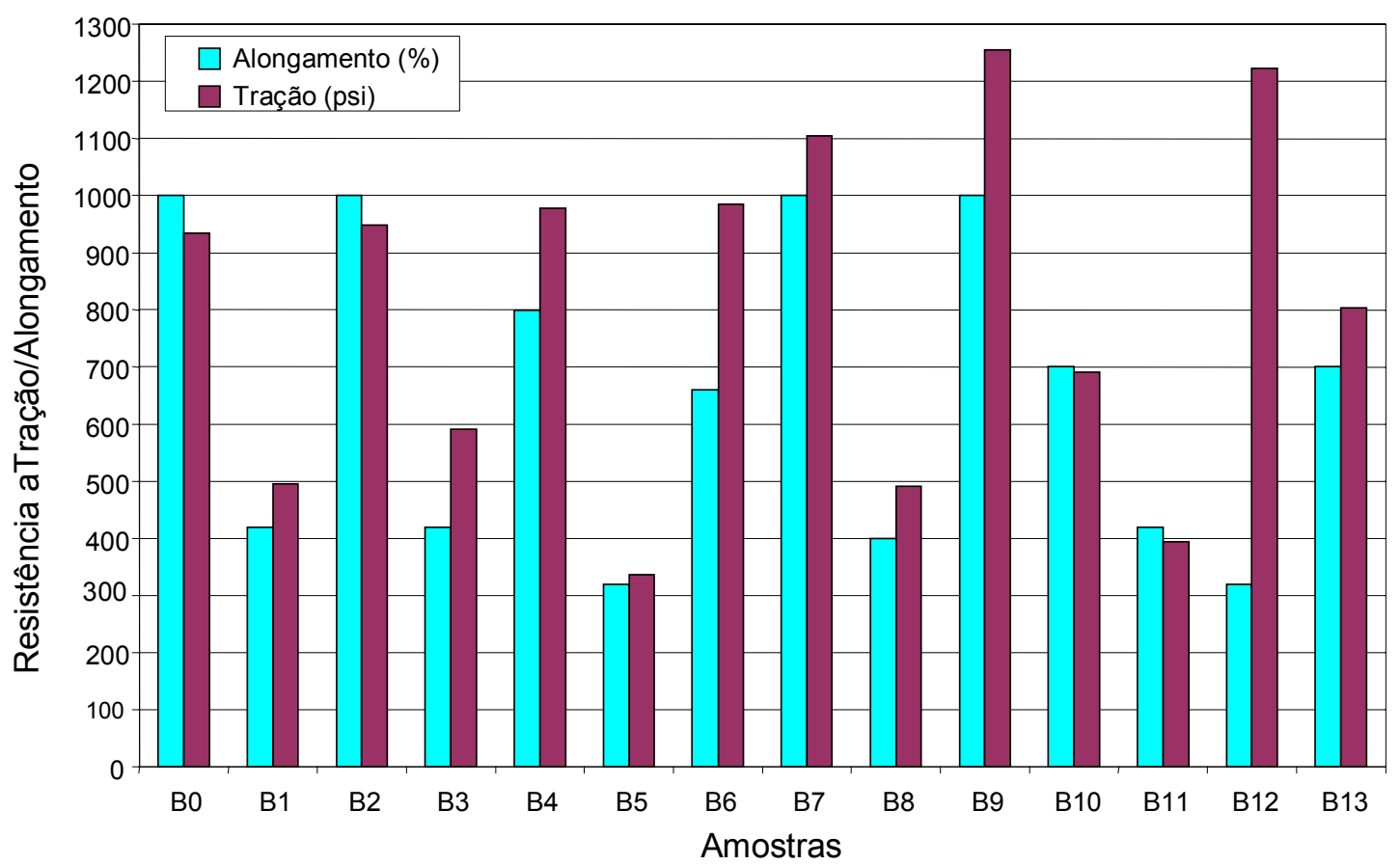

FIGURA 24 - Variação de Tração/Alongamento da composição de CR com $\mathrm{SiO}_{2}$.

As amostras irradiadas foram processadas novamente no cilindro de rolos, de maneira similar ao que foi feito para aquelas formuladas com NF. Foi possível confeccionar corpos-de-prova para todas as massas obtidas. Os resultados foram pouco satisfatórios, pois algumas apresentavam aspecto deformado e odor de borracha queimada e, ainda, possuíam aparência quebradiça ou pegajosa, indicando que ocorreu degradação ou perda de elasticidade. Em muitos casos, houve até mudança da cor padrão (bege para preto ou marrom escuro), conforme mostrado na FIG.25. O estudo das curvas reométricas também demonstrou que houve alterações significativas nos parâmetros de vulcanização, conforme mostrado anteriormente na FIG. 22. 


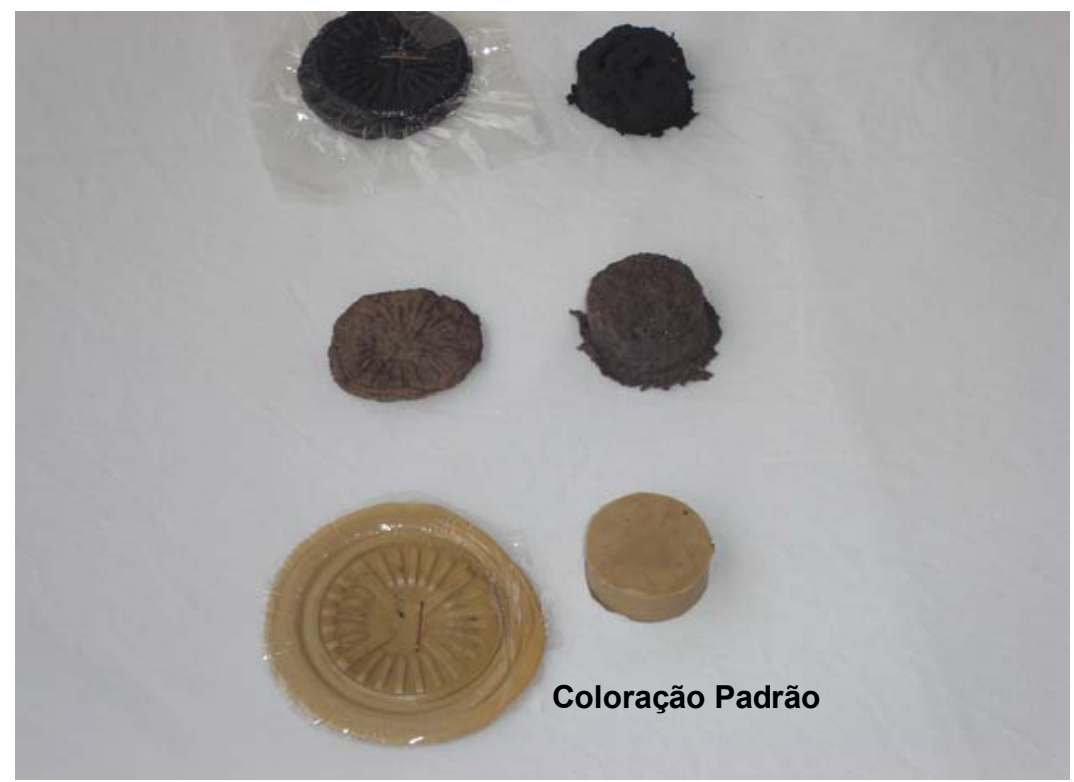

Figura 25 - Corpos-de-prova de $\mathrm{CR}$ com $\mathrm{SiO}_{2}$, cor padrão alterada pela irradiação.

A degradação de algumas amostras é demonstrada nas variações dos parâmetros de dureza, resistência à tração e alongamento. Foram realizados, ainda, teste de inchamento para determinar a densidade das ligações cruzadas, notou-se que a amostra original (B0) inchou mais que as amostras irradiadas (FIG. 26), a variação dos índices de inchamento é demonstrado na FIG. 27. Aparentemente, verifica-se que as amostras foram degradadas.

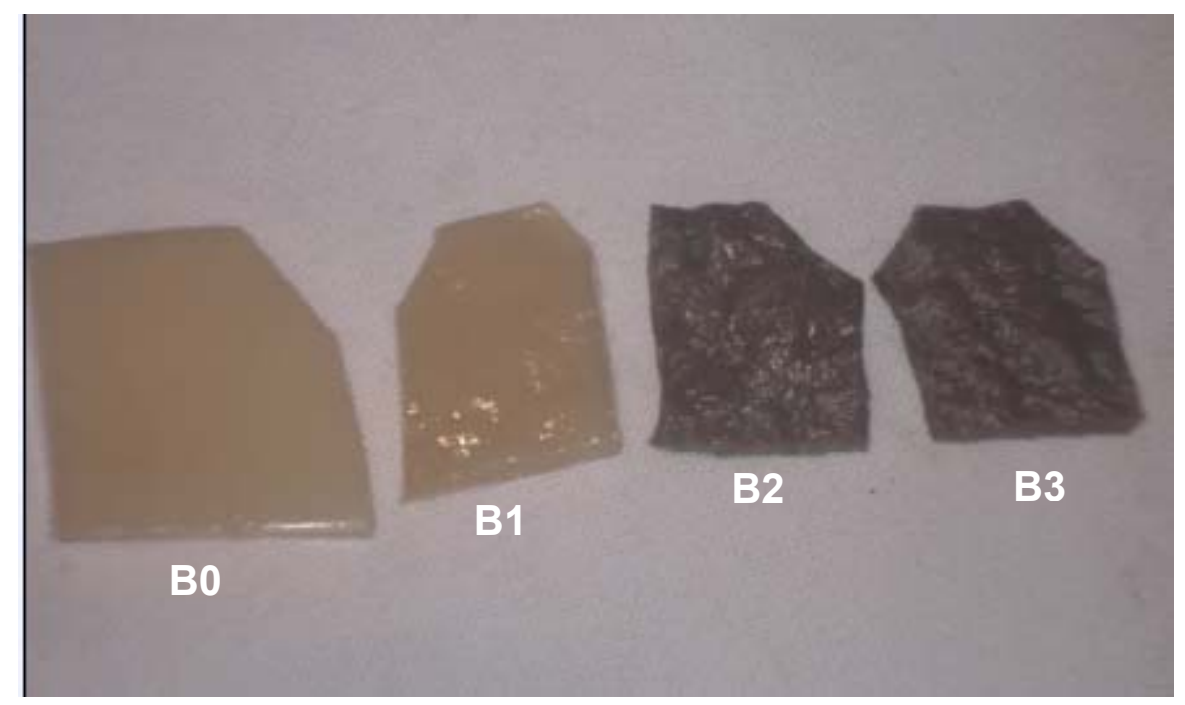

Figura 26 - Amostras da composição de $\mathrm{CR}$ com $\mathrm{SiO}_{2}$ após imersão no solvente. 


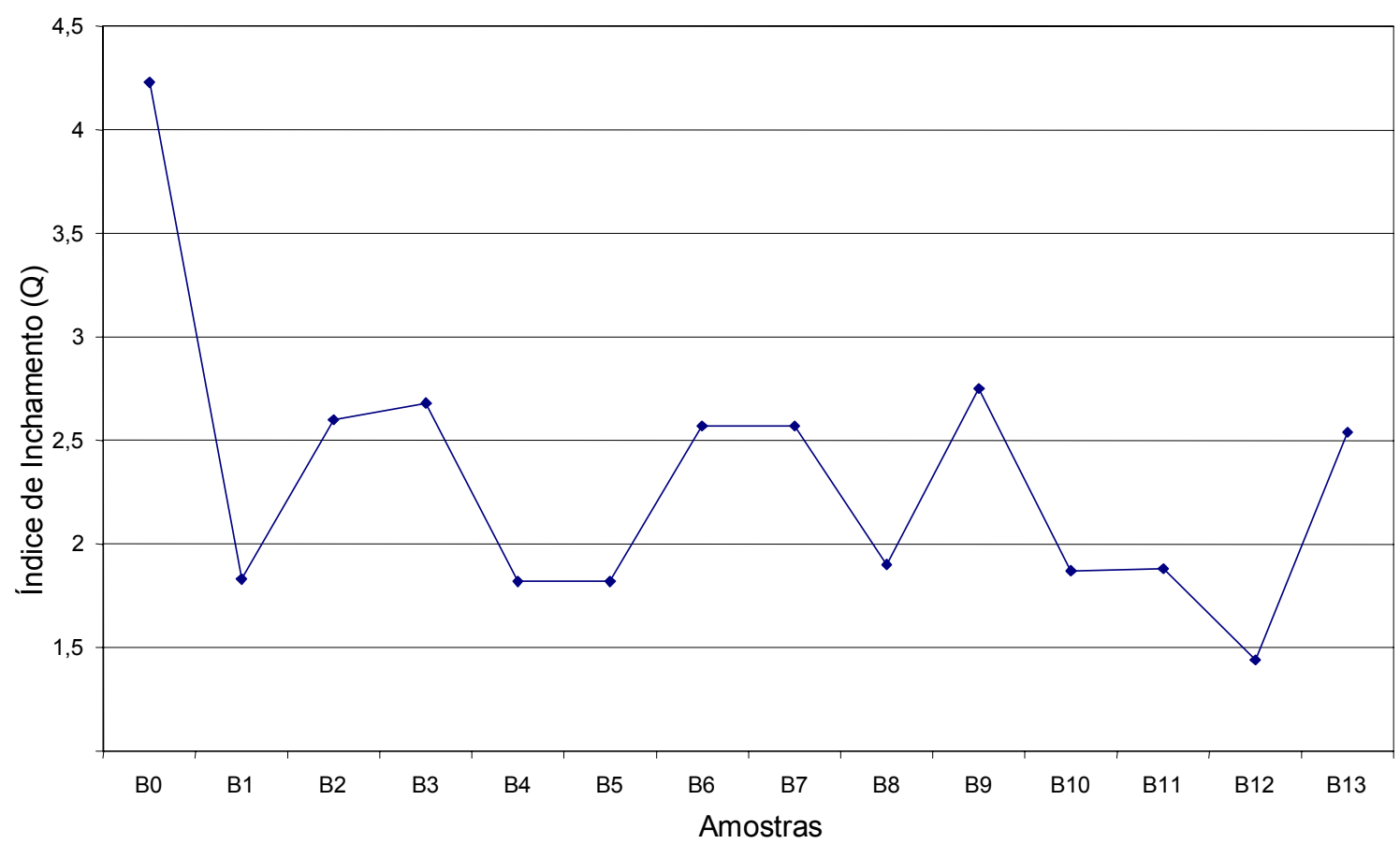

FIGURA 27- Variação dos índices de inchamento da composição de CR com SiO2

O fato de estas amostras apresentarem resultados pouco satisfatórios pode ter sido causado pela dificuldade da incorporação e dispersão da sílica precipitada no composto (tamanho das partículas e pequena densidade aparente). Outra característica particular das sílicas é a porosidade superficial das partículas, que tendem a tirar parte dos aceleradores, desequilibrando o sistema de cura.

Sendo assim, estes tipos de amostras foram descartados para uso como carga ativa em novos compostos de borracha.

Como as amostras de CR formuladas com NF apresentaram melhores resultados que aquelas com $\mathrm{SiO}_{2}$, após as irradiações, foram empregadas como matéria-prima, para realização de misturas em diferentes proporções com borracha virgem.

Como citado anteriormente, a amostra A2 foi a que apresentou resultados mais satisfatórios, com aparência mais mole e deformada, sem odor característico de borracha queimada. Portanto, foi escolhida como ponto de partida para realizar os referidos testes de mistura de carga. 
Em seguida, foram efetuadas diversas combinações entre a borracha virgem e irradiada; mantendo-se a formulação original do composto de CR, conforme mostrado na TAB. 12.

TABELA 12 - Combinações de borracha virgem e irradiada.

\begin{tabular}{c|c|c}
\hline Amostra & $\begin{array}{c}\text { Borracha } \\
\text { Virgem } \\
\text { (phr) }\end{array}$ & $\begin{array}{c}\text { Borracha } \\
\text { Devulcanizada } \\
\text { (phr) }\end{array}$ \\
\hline A0 & 100 & 0 \\
\hline M1 & 97 & 3 \\
\hline M2 & 95 & 5 \\
\hline M3 & 90 & 10 \\
\hline M4 & 85 & 15 \\
\hline M5 & 80 & 20 \\
\hline M6 & 75 & 25 \\
\hline M7 & 70 & 30 \\
\hline M8 & 65 & 35 \\
\hline M9 & 50 & 50 \\
\hline
\end{tabular}

Para estas massas foram preparados corpos-de-prova, utilizando-se prensa (Luxor), em $160^{\circ} \mathrm{C}$ por $15 \mathrm{~min}$, conforme norma ASTM D-3182 ${ }^{41}$. Os resultados obtidos com as caracterizações são mostrados na TAB. 13.

Tabela 13 - Caracterizações das massas de CR irradiada e original.

\begin{tabular}{c|c|c|c|c|c|c}
\hline Amostra & $\begin{array}{c}\text { Dureza } \\
(\text { shore A) }\end{array}$ & $\begin{array}{c}\text { Densidade } \\
\text { (g/cm }^{\mathbf{3}} \mathbf{)}\end{array}$ & $\begin{array}{c}\text { Tração } \\
\text { (psi) }\end{array}$ & $\begin{array}{c}\text { Alongamento } \\
\mathbf{( \% )}\end{array}$ & $\begin{array}{c}\text { Cinzas } \\
\mathbf{( \% )}\end{array}$ & $\begin{array}{c}\text { DPC } \\
\text { (\%) }\end{array}$ \\
\hline A0 & 57 & 1,40 & 1428 & 500 & 14,09 & 20,46 \\
\hline M1 & 64 & 1,39 & 1929 & 500 & 12,08 & 15,25 \\
\hline M2 & 60 & 1,36 & 1917 & 600 & 11,62 & 27,65 \\
\hline M3 & 60 & 1,37 & 1925 & 800 & 13,53 & 52,88 \\
\hline M4 & 59 & 1,38 & 1925 & 600 & 14,30 & 30,50 \\
\hline M5 & 64 & 1,26 & 2242 & 480 & 16,25 & 34,35 \\
\hline M6 & 63 & 1,39 & 1924 & 600 & 16,84 & 30,46 \\
\hline M7 & 63 & 1,47 & 1921 & 520 & 16,20 & 28,07 \\
\hline M8 & 65 & 1,37 & 1783 & 480 & 16,60 & 15,43 \\
\hline M9 & 72 & 1,43 & 1597 & 420 & 18,08 & 27,08 \\
\hline
\end{tabular}

De acordo com a TAB. 13, observa-se que a mistura de borracha irradiada por microondas com borracha virgem causou efeitos em algumas 
propriedades. Os valores de dureza e de resistência a tração foram aumentados, bem como aqueles para DPC (na maioria das amostras). Estes resultados são justificados pela diminuição na flexibilidade das cadeias macromoleculares, em virtude da presença de borracha irradiada. A adição deste tipo de borracha pode ser desejável ou não, dependendo do tipo de artefato que será fabricado. Desta maneira, o teste de resistência ao envelhecimento acelerado foi incluído nas caracterizações, para avaliar a quantidade de borracha irradiada, que adicionada à borracha virgem, poderia afetar o tempo de vida útil das massas, o envelhecimento foi medido depois de 70 horas a $100 \pm 2^{\circ} \mathrm{C}$. Os resultados são mostrados na TAB. 14, e a variação destes parâmetros estão demonstradas na FIG. 28. Analisando-se os resultados obtidos, observou-se que a inclusão de borracha irradiada acima de 10 partes aumenta em torno de $12 \%$ o alongamento, mas não aumenta mais que $5 \%$ os valores de dureza (porcentagem que pode ser aceita para fabricação de algumas peças de cloropreno).

TABELA 14 - Resultados do teste de envelhecimento de massas de CR irradiada e original $(\mathrm{A} 0)$.

\begin{tabular}{c|c|c|c}
\hline Amostra & $\begin{array}{c}\text { Variação de } \\
\text { Dureza } \\
\mathbf{( \% )}\end{array}$ & $\begin{array}{c}\text { Variação de } \\
\text { Tração } \\
\mathbf{( \% )}\end{array}$ & $\begin{array}{c}\text { Variação } \\
\text { Alongamento } \\
\mathbf{( \% )}\end{array}$ \\
\hline A0 & 0 & 3,01 & 2,40 \\
\hline M1 & 1,56 & 3,50 & 3,54 \\
\hline M2 & 3,33 & 3,94 & 16,66 \\
\hline M3 & 3,33 & 9,16 & 25,00 \\
\hline M4 & 3,77 & 4,67 & 13,33 \\
\hline M5 & 3,56 & 6,37 & 12,33 \\
\hline M6 & 3,86 & 5,32 & 26,66 \\
\hline M7 & 4,76 & 7,22 & 15,38 \\
\hline M8 & 4,61 & 9,47 & 12,50 \\
\hline M9 & 4,16 & 8,64 & 14,28 \\
\hline
\end{tabular}




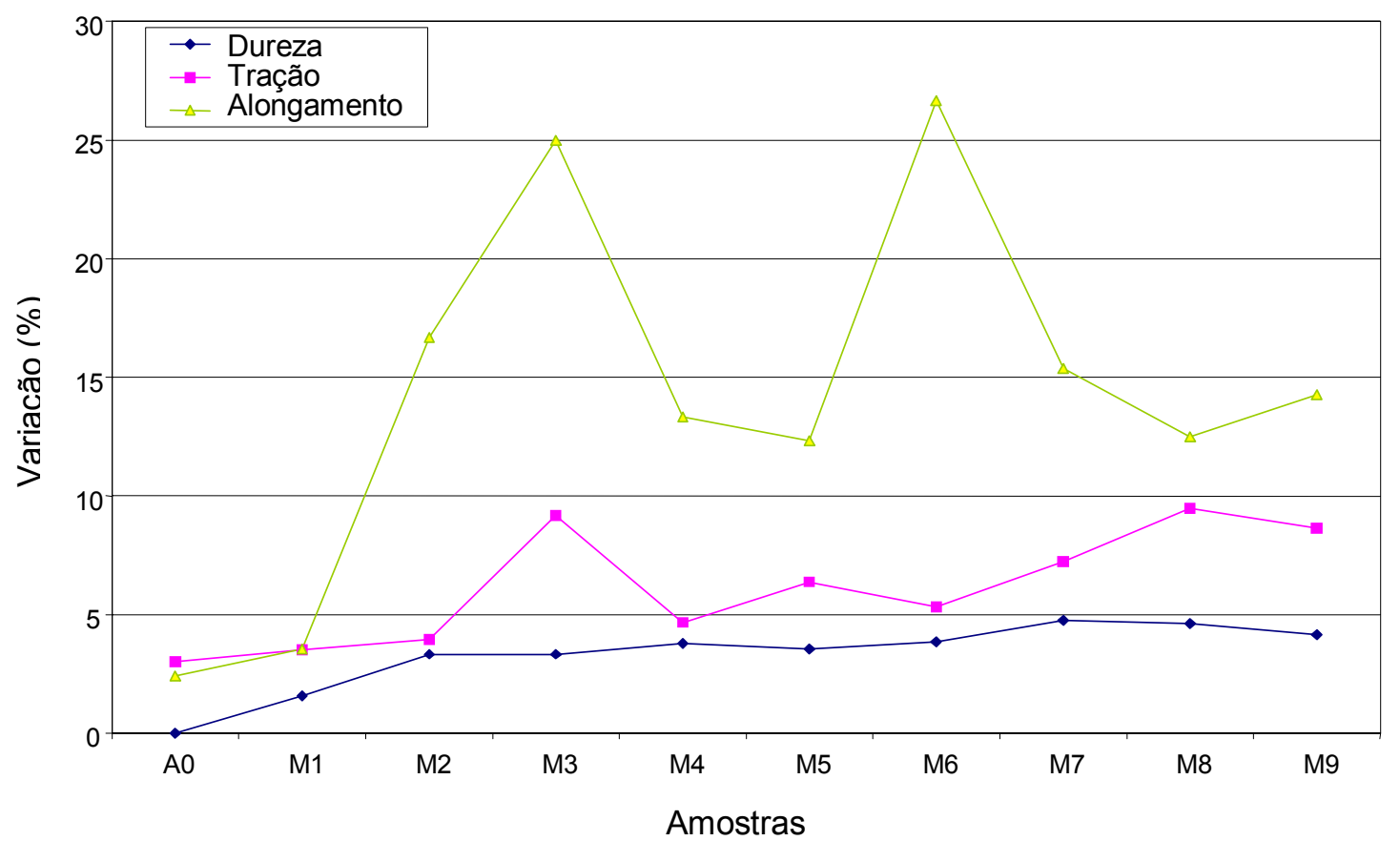

FIGURA 28 - Variação dos parâmetros de envelhecimento para massas de CR irradiadas, misturadas com a original (A0).

Como foi mantida a formulação original, estas massas foram submetidas à análise reométrica, com temperatura de $160^{\circ} \mathrm{C}$, por $12 \mathrm{~min}$, para verificação dos parâmetros de vulcanização, como pode ser visto na FIG.29. 


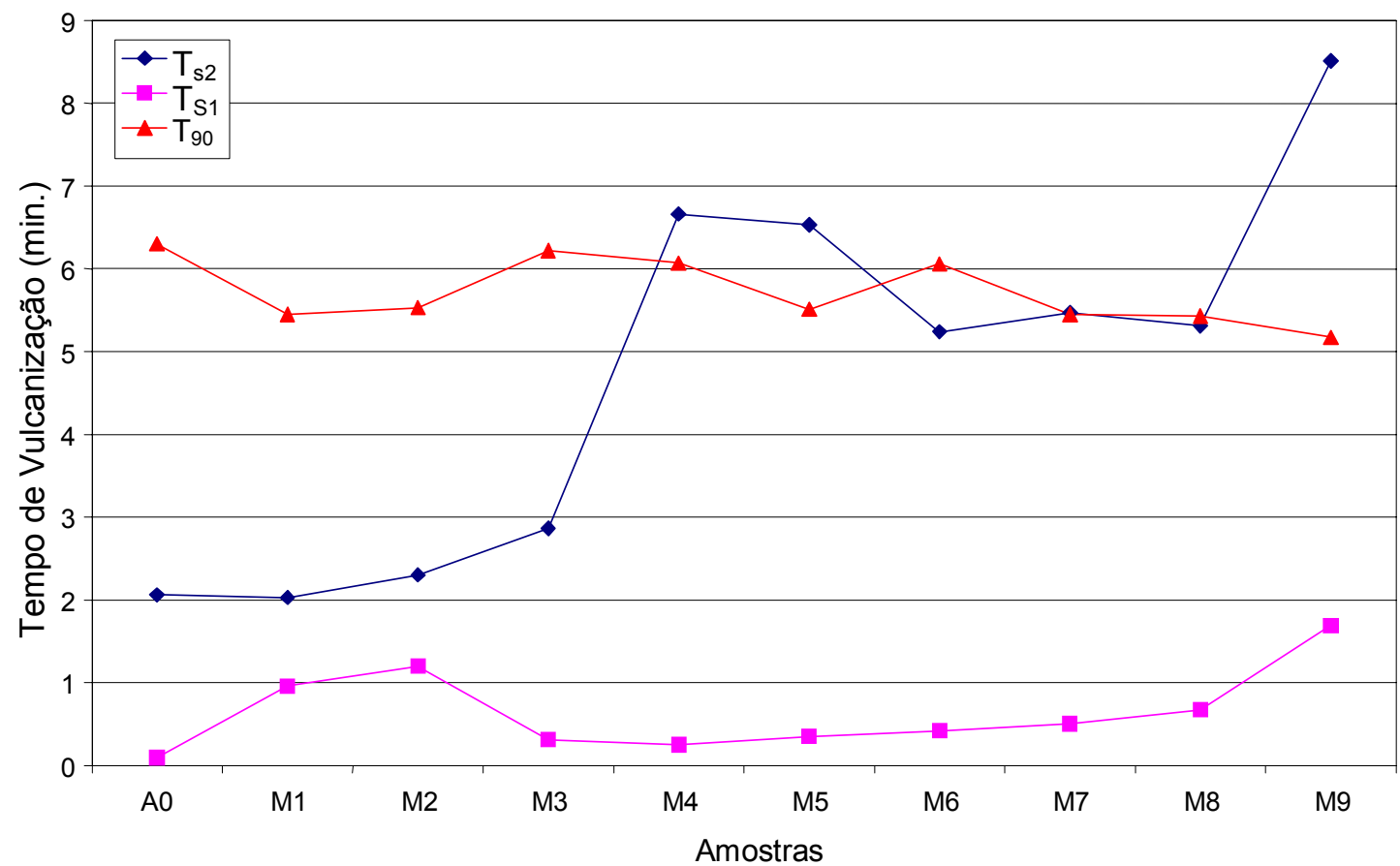

FIGURA 29- Parâmetros de vulcanização das massas de CR irradidas e original.

Os valores de tgo $_{90}$ no foram muito alterados. Porém, verifica-se que para $T_{S 1}$ e $T_{S 2}$ as variações ocorridas podem afetar o processamento das massas, na etapa de vulcanização. Isto pode ser observado, principalmente a partir da massa M4 (15 partes de borracha irradiada), que apresentou uma diferença muito grande entre os valores de $\mathrm{T}_{\mathrm{S1}}$ e $\mathrm{T}_{\mathrm{S} 2}$.

Foram analisados também os valores obtidos para dureza, resistência a tração e alongamento, conforme resultados mostrados nas FIG.30 e FIG.31 respectivamente. 


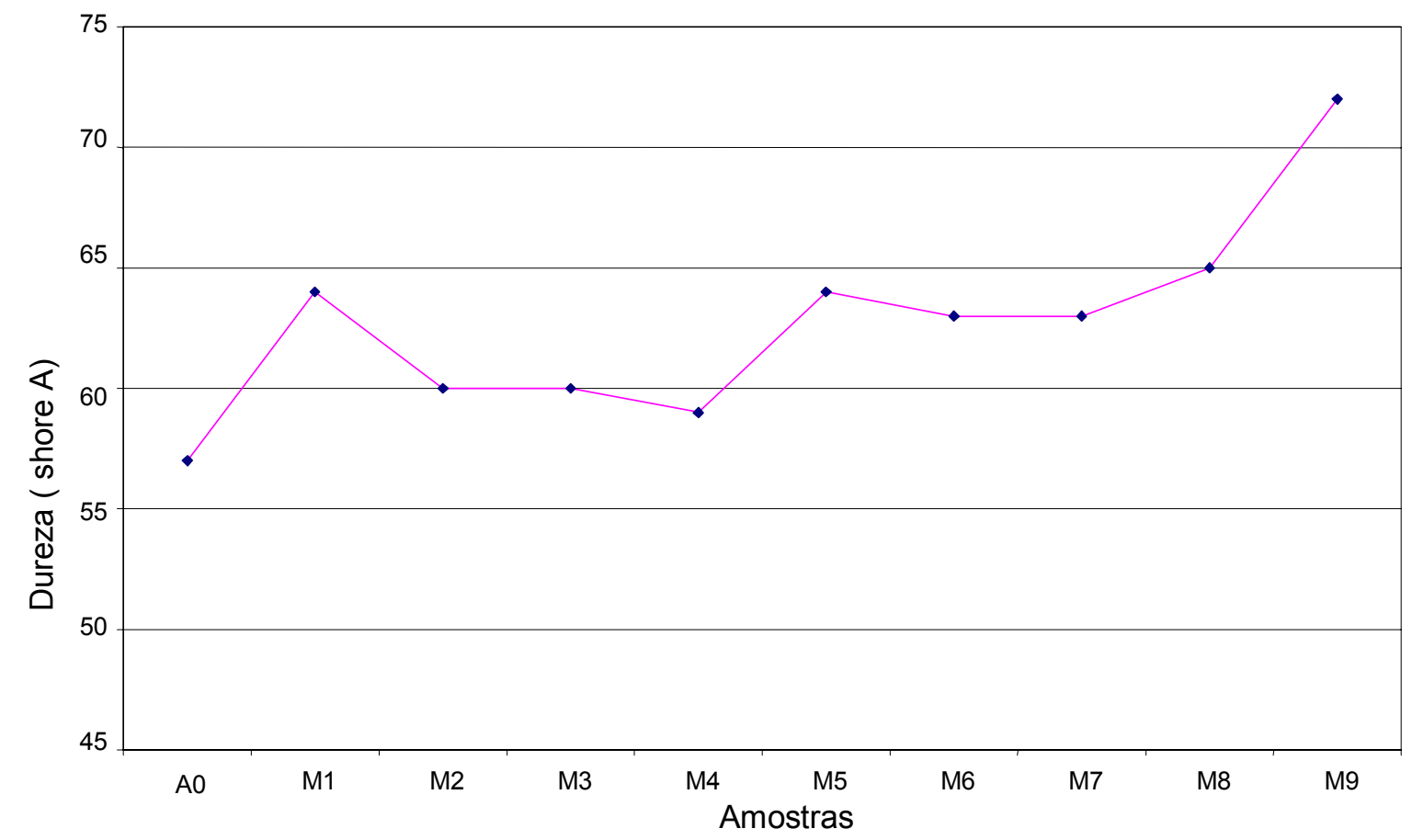

FIGURA 30 - Variação dos valores de dureza das massas de CR irradiadas e original.

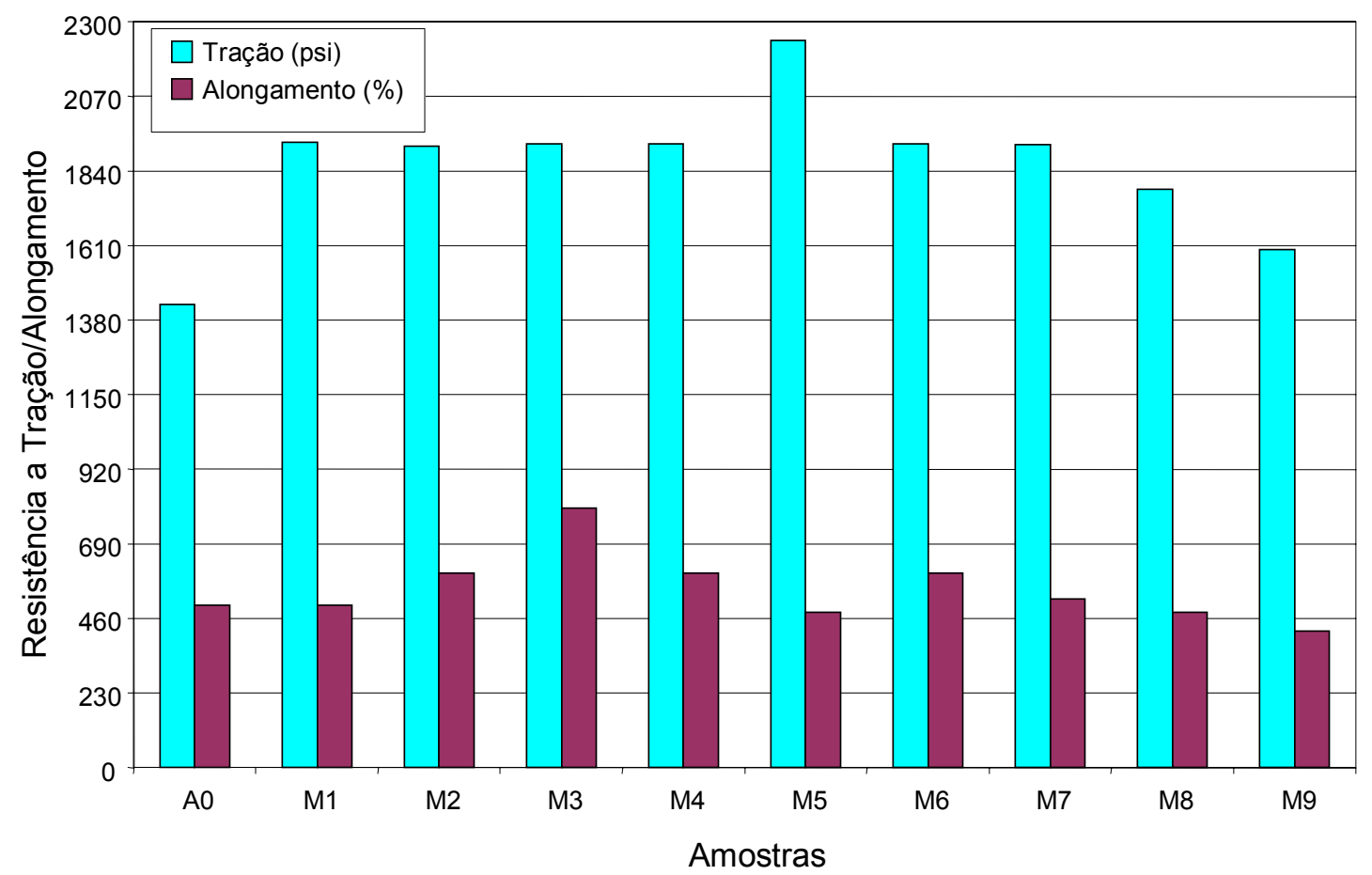

FIGURA 31 - Variação de Tração/Alongamento da composição de CR irradiadas e original. 
Baseando-se nos resultados mostrados na TAB.13 e FIG.28, FIG.30 e FIG.31, verifica-se que as propriedades das misturas (M1 a M9) são satisfatórias, para serem usadas na fabricação de artefatos. Em alguns casos, a adição de borracha irradiada causa redução em algumas propriedades e aumento em outras (dureza e resistência a tração). Portanto, um aumento no valor destes dois parâmetros pode significar que o produto ficou mais duro, desejável ou não, dependendo da aplicação (especificação). As massas obtidas foram empregadas na fabricação de peças de cloropreno, para uso em indústria automobilística. Elas foram distribuídas para confecção dos seguintes artefatos:

- Massa 1 e Massa 2 - batente para banco da moto Honda BIS 125.

- Massa 3 e Massa 4 - tubo do dreno do filtro de ar

- Massa 5 e Massa 6 - vedação do filtro de óleo (Filtros MAN), para diversos tipos de veículos

- Massa 7 e Massa 8 - peça que encaixa no amortecedor traseiro de alguns automóveis

- Massa 9 - gaxeta para o motor do Fiat

As peças obtidas com estas massas apresentaram aspecto visual semelhante ao das fabricadas com borracha virgem, conforme pode ser observado na FIG. 32.

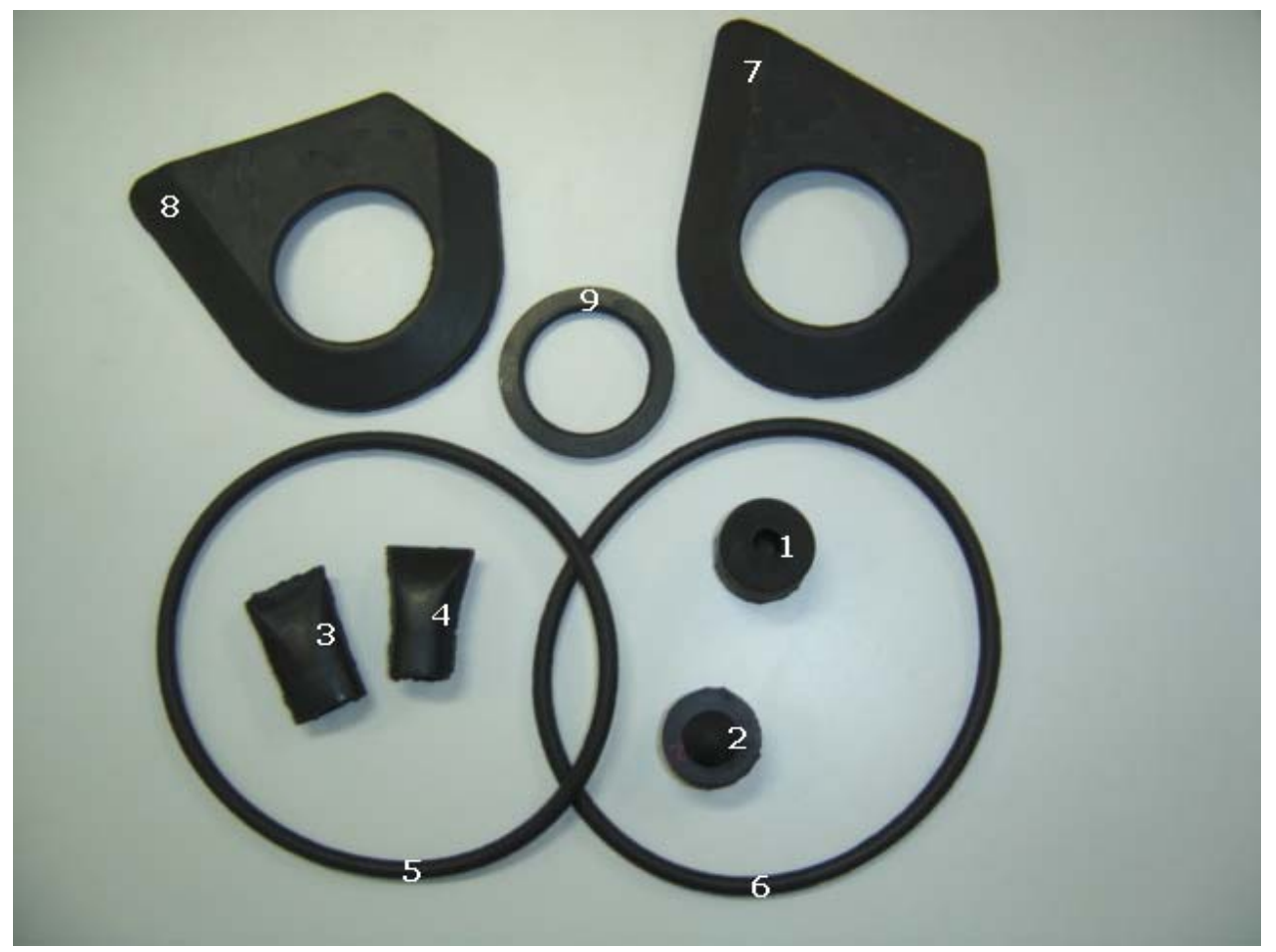

FIGURA 32 - Peças fabricadas com borracha CR irradiada e original. 


\section{CONCLUSÕES}

Todos os ensaios realizados neste trabalho foram importantes, pois indicaram que as amostras de cloropreno tiveram alterações em suas propriedades físicas e químicas.

No caso do composto formulado com bióxido de silício, como carga, os resultados foram pouco satisfatórios, pois algumas apresentavam aspecto deformado e odor de borracha queimada e, ainda, possuíam aparência quebradiça ou pegajosa, indicando que ocorreu degradação ou perda de elasticidade. Isto foi confirmado pelo estudo das curvas reométricas, que indicaram alterações significativas nos parâmetros de vulcanização.

Como as amostras de CR formuladas com negro de fumo apresentaram melhores resultados que aquelas com bióxido de silício, após as irradiações, foram empregadas como matéria-prima, para realização de misturas em diferentes proporções com borracha virgem. As massas obtidas após as misturas apresentaram tendência de vulcanizar novamente. Isto pode ser verificado, principalmente, pelas peças de cloropreno fabricadas. Desta maneira, proporções de borracha irradiada, incluídas na formulação de cloropreno, poderão substituir algumas partes da borracha virgem.

Algumas propriedades inadequadas apresentadas nas misturas (borracha virgem e irradiada) poderão ser compensadas pela adição de produtos químicos ou ajuste de processos. Existem grandes expectativas no seu uso, para fabricação de alguns artefatos automobilísticos. Porém, não foram feitas avaliações econômicas, para utilização comercial, tanto do processo como do material.

Baseando-se nos resultados experimentais, pode-se dizer ainda que é necessário interpretar como o produto fabricado com a borracha irradiada se comportará durante a mistura e a manufatura do artefato. Portanto, é conveniente realizar testes específicos, para cada peça, para avaliar se as porcentagens de borracha irradiada, misturadas à borracha virgem, têm o mesmo desempenho que aquelas fabricadas sem essa mistura.

Uma observação que pode ser feita, ainda, é que as peças foram fabricadas sem o uso de qualquer aditivo químico, o que é de suma importância na preservação do meio ambiente. 
Neste tipos de borrachas formuladas com negro de fumo e bióxido de silício, o processamento com microondas provocou tanto efeitos negativos (degradação), quanto positivos (nova reticulação). Porém, é necessário realizar mais estudos sobre este assunto, para avaliação da confiabilidade do método proposto.

Como o interesse pela devulcanização e reciclagem de borrachas tem aumentado nos últimos anos, em virtude das regulamentações governamentais nacionais e internacionais, para gerenciamento destes tipos de materiais, este é um método potencial de reciclagem de borrachas, desde que os restos de borracha possam ser revulcanizados para produção de artefatos. 


\section{REFERÊNCIAS BIBLIOGRÁFICAS}

1 ADHIKARI, B.; DE, D.; MAITI, S. Reclamation and Recycling of Waste Rubber. Progress in Polymer Science, v. 25, n. 7, p. 909-948, 2000.

2 PAPAUTSKY, D. Borracha Recuperação e Regeneração. Borracha Atual, v. 45, p.42-50, 1999.

3 GARBIN, V.J. Neoprene, Características, Compostos e Aplicações. Borracha Atual, v. 17, p. 16-29, 1998.

4 WIEBECK, H.; ESPER, F.; FEIJÓ, A.C. Tecnologia da Borracha. Cooperação Universidade Empresa CECAE/USP, 2002.

5 KLEPS, T.; PIASKIEWICZ, M.; PARASIEWICS, W. The use of thermogravimetry in the study of rubber devulcanization. Journal of Thermal Analysis and

Calorimetry, v. 60, p. 271-277, 2000.

6 NOVOTNY, D.S.; WINDSOR, V.; MARSH, R.L.; SPRINGFIELD, M.; MASTERS, F.C.; PALMIRA, N.; TALLY D.N.; ARVADA, C. Microwave Devulcanization of Rubber, US Patent 4104205, 01 aug. 1978.

7 ROCHA, E.C.; LOVISON, V.M.H.; PIEROZAN, N.J. Tecnologia de

Transformação dos Elastômeros, Centro Tecnológico de Polímeros SENAICETEPO, São Leopoldo, 2000.

8 SANTOS, G.R.; MOTHÉ, C.G. Prospecção e perspectivas da borracha natural, Hevea brasiliensis. Revista Analítica, n.26, p.32-34, 2007.

9 HAGE Jr., E.; PESSAN, L.A. Aperfeiçoamento em Tecnologia de Plásticos Correlação entre processamento, estrutura e propriedades dos polímeros Módulo 6. Universidade Federal de São Carlos, Departamento de Engenharia de Materiais, 2002.

10 MONTENEGRO, R.S.P.; PAN, S.S.K. Panorama do Setor de Borrachas. Disponivel em: <http://www.bndespar.com.br/conhecimento/bnset/borrach2.pdf>. Acesso em: 5 dez. 2006.

11 ANNUAL BOOK OF ASTM STANDARDS. Standard Terminology Relating to Rubber, v. 09,01, 1996 (ASTM D-1566). 
12 AHEMED, R.; KLUDENDERT, A.V.; LARDINOIS, I. - Ruber Waste - Options for Small-scale Resource Recovery- Urban Solid Waste, Series 3 ,Chap.1, p.11, 1996. Disponível em:

http://www.waste.nl/content/download/292/23309/file/uw3\%20rubber\%20eng\%20e book.pdf. >. Acesso em: 4 nov. 2006.

13 COSTA, H.M.; VISCONTE L.L.Y.; NUNES R.C.R.; FURTADO C.R.G. Aspectos Históricos da Vulcanização - Polímeros Ciência e Tecnologia, v.13, n.2, p.125129, 2003.

14 PETROFLEX. A Borracha - Um pouco da história da borracha.

Disponível em: <http://www.petroflex.com.br/perfil_borracha.htm>. Acesso em: 21 jan. 2007.

15 CWC DEVULCANIZATION - MICROWAVE. Best Practices in Tires \& Rubber Recycling. Disponível em: <http://www.cfc.org>. Acesso em: 22 mai. 2005.

16 LLOYD, C.A. Evaluation of Waste Tire Devulcanization Technologies. Califórnia Environmental Protection Agency, State of Califórnia, Chap. 2, p.4, 2004. Disponível em:

<http://www.ciwmb.ca.gov/Publication/Tires/62204008.pdf>. Acesso em: 18 fev. 2006.

17 SUTANTO, P. Development of a Continuous Process for EPDM Devulcanization in a Extruder. Chap.1. Disponível em:

<http://dissertations.ub.rug.nl/FILES/faculties/science/2006/p.sutanto/01_c1.pdf.>. Acesso em: 19 jan. 2007.

18 CHRISTOFI, N.; GEOFFREY, J.; EDWARD, D. Rubber Treatment Method. US Patent 2006/0293398 A1, 28 dec.2006.

19 MARTINES, M.A.U.; DAVOLOS, M.R.; JAFELICCI JÚNIOR, M. O efeito do ultra-som em reações químicas. Química Nova, v.23, n.2, p.251-256, 2000.

20 ISAYEV, A.; CHEN, J. Continuos Ultrasonic Devulcanization of Vulcanized Elastomers, US Patent 5284625, 8 feb.1994.

21 HAQUE, K.E. Microwave energy for mineral treatment process - a brief review. Internacional Journal of Mineral Processing, v. 57, n.1, p.1-24, 1999.

22 RAKHMANKULOV, D.L.; SHAVSHUKOVA, S.YU; LATYPOVA, F.N.; ZORIN, V.V. Laboratory and Industrial Applications of Microwave Techniques. Russian Journal of Applied Chemistry, v.75, n.9, p.1377-1383, 2002. 
23 ROmiLL - Industrial Microwave Heating. Disponível em:

<http://romill.cz/index.php?lang=eng\&show_dir=68>. Acesso em: 08 jul. 2006.

24 ZHOU, J.; SHI, C.; MEI, B.; YUAN, R.; FU, Z. Research on the technology and the mechanical properties of the microwave processing of polymer. J. Materials Processing Technology, v.137, p.156-158, 2003.

25 JEON, J.Y.; KIM, H.Y. Microwave irradiation effect on diffusion of organic molecules in polymer. European Polymer Journal. v.36, p.895-899, 2000.

26 BARBOZA, A.C.R.N.; CRUZ, C.V.M.S.; GRAZIANI, M.B.; LORENZETTI, M.C.F.; SABADINI, E. Aquecimento em forno de microondas/desenvolvimento de alguns conceitos fundamentais. Educação Química Nova, v.24, n.6, p.901-904, 2001.

27 KU, H.S.; SIORES, E.; TAUBE, A.; BALL, J.A.R. Productivity improvement through the use of industrial microwave technologies. Computer \& Industrial Engineering, v. 42, p. 281-290, 2002.

28 GARBIN, V.J. Artigos Técnicos - Elastômeros - Neoprenes. Disponível em <http://www.vulcanizar.com.br/bibliografia/t_cr.html>. Acesso em: 20 jul. 2005

29 MURRAY, R.M; THOMPSON, D.C. Os Neoprenes, Elastomer Chemicals Department- E.I. DuPont de NEUMOURS \& CO, p.xi-xii, 1964.

30 PETROFLEX, Disponível em:

http://www.flexglobal.com.br/pt/pefxvoce/apresentacoes/20060321_elastomeros_p efx.pdf, Acesso em 06 fev.2007.

31 R. T. THE VANDERBILT COMPANY, INC. The Vanderbilt Rubber Handbook. 13.ed. Norwalk,1990.

32 ANNUAL BOOK OF ASTM STANDARDS. Standard Classification System for Rubber Products in Automotive Applications. v. 09.02, 1996 (ASTM D-2000).

33 ANDERSON, E. E.; VIEW, M. Method and Apparatus for Microwave Heating of Flowable Material. US Patent 4129768, 12 dec.1978.

34 HAYASHI, K.; SUMIDA, A.; NITZA ,T.M.; FUZIMI, T. M. Method for Reclamation of Vulcanized Rubber, US Patent 4469817, 4 sep.1984. 
36 HUNT, J.R.; HALL, D. Process for Reclaiming Elastomeric Waste. US Patent 5362759, 8 nov.1994.

37 WICKS, G. G.; SCHULZ, R. L; CLARK, D. E.; FOLZ, D. C. Microwave Treatment of Vulcanized Rubber. US Patent 6420457, 16 jul.2002.

38 FILERMANS, C.B.; WICKS, G. G. Combination Biological and Microwave Treatments of Used Rubber Products. US Patent 6407144 B1, 18 jun.2002.

39 YOO, T.W.; HONG, J.H.; LEE, B.C; PARK, H.H. Apparatus and Method for Continuosly Treating Surface of Waste Powder Using Microwave. US Patent 2006/0033234 A1, 16 feb.2006.

40 MARTINS, A.F; NAPOLITANO, B.A.; VISCONTE, L.L.Y.; NUNES, R.C.R. Propriedades Mecânicas e Dinâmicas de Composições de Policloropreno com Negro de Fumo. Polímero Ciência e Tecnologia, v. 12, n. 3, p. 147-152, 2002.

41 ANNUAL BOOK OF ASTM STANDARDS. Standard Practice for RubberMaterials, Equipament, and Procedures for Mixing Standart Compounds and Preparing Satndard Vulcanized Sheets , v. 09.01, 1996 (ASTM D-3182).

42 ARAÚJO, S.G.; LANDINI, L.; LIMA, L.T.; GHILARDI, E.; ANTUNES, R.A.; PEREIRA, A.A.A.V.; SILVA, R.J.L.; LUGÃO, A.B. Desenvolvimento de um Dispositivo de Microondas para Irradiação e Recuperação de Polímeros Reticulados. In: $7^{\circ}$ CONGRESSO BRASILEIRO DE POLÍMEROS, 11., 2003, Belo Horizonte. Anais... Belo Horizonte, 2003. CD-ROM.

43 ANNUAL BOOK OF ASTM STANDARDS.Standard Test Methods for Rubber Products - Chemical Analysis, v. 09.01, 1996 (ASTM D-297).

44 ANNUAL BOOK OF ASTM STANDARDS. Standard Test Method for Rubber Property - Durometer Hardness, v. 09.01, 1996 (ASTM D-2240).

45 ANNUAL BOOK OF ASTM STANDARDS. Standard Test Methods for Vulcanized Rubber and Thermoplastic Rubber and Thermoplastic Elastomers - Tension, v. 09.01, 1996 (ASTM D-412).

46 ANNUAL BOOK OF ASTM STANDARDS. Standard Test Method for Rubber - Deterioration in Air Oven, v. 09.01, 1996 (ASTM D-573).

47 ANNUAL BOOK OF ASTM STANDARDS. Standard Test Method for Rubber Property - Compression Set, v. 09.01, 1996 (ASTM D-395).

48 ANNUAL BOOK OF ASTM STANDARDS. Standard Test Method for Rubber Property - Vulcanization Using Oscillating Disk Cure, v. 09.01, 1996 (ASTM D2084). 
49 ADACHI, K.; NAKAMOTO, T.; KOTAKA, T. Swelling Equilibrium of Solution Cross-Linked Polybutadieno Networks in Polyisoprene Solutions,

Macromolecules, v.22, p. 3106-3111, 1989.

50 ANNUAL BOOK OF ASTM STANDARDS. Standard Test Method for Rubber, Raw - Determination of Gel, Swelling Index, and Dilute Solution Viscosity, v.09.01, 1996 (ASTM D-3616).

51 GHANI, S.A.; MADKOUR, T.M.; OSMAN, H.M.; MOHAMED, A.R. Study of the Eletrical Properties and Swelling Mechanism in Compressed Butyl Rubber Loaded with Carbon Black, Journal of Applied Polymer Science, v.81, n. 13, p. 3169 3177, 2001. 